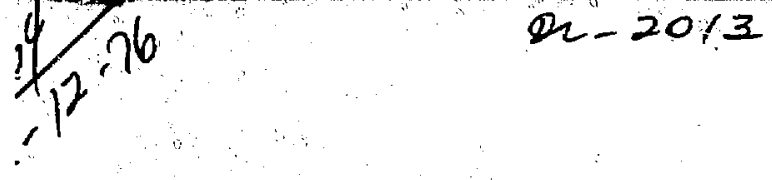

\title{
A METHODOLOGY FOR IMPACT ASSESSMENT IN THE ESTUARINE/MARINE ENVIRONMENT
}

Kendail F." Hoven

October 31, 3975

Prepared for U.S. Energy Research \& Development Administration under contract No. W-7405-Er.g-48

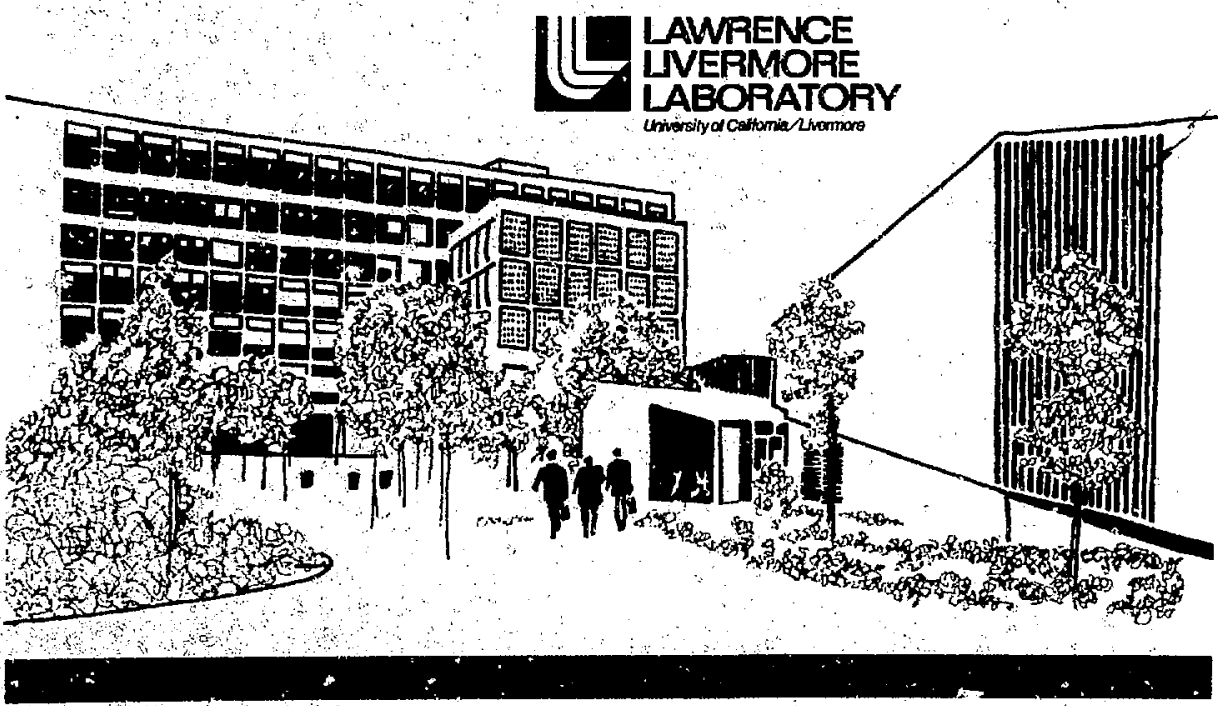


NOTICE

'Thl cupost was prepared as an account of work aponpored by the United States Government. Neither the United States nor the United Stutes Enersy Revench a Development Administration, not any of their employets, nor any of their contractors. cubcontrectors, or theit emplayees, makes eny warranty, expres or implied, or assumes any besil Hobitity or responsibility for the accuracy. complotenes of usefulness of any information, apperatus, product or process dinclosed, or reprevents that its use would not infinge privately-owned sthts."

Printed in the United States of America Available from

National Technical Information Service

U. S. Department of Commerce 5285 Port Royal Road Springfield, Virginia 22151

Price: Printed Copy \$_ *; Microfiche \$2.25

\begin{tabular}{rr}
${ }^{*}$ Pages & $\begin{array}{r}\text { NTIS } \\
\text { Selling PI }\end{array}$ \\
\hline $1-50$ & $\begin{array}{r}\$ 4.00 \\
51-150\end{array}$ \\
$151-325$ & $\$ 5.45$ \\
$326-500$ & $\$ 7.60$ \\
$501-1000$ & $\$ 10.60$ \\
& $\$ 13.60$
\end{tabular}




\title{
近 \\ LAMEENCE LNEFWORE LAEORATOFY

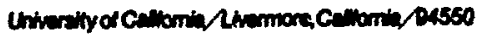

\section{UCRL-51949 \\ A METHODOLOGY FOR IMPACT ASSESSMENT IN THE ESTUARINE/MARINE ENVIRONMENT}

\author{
Kendall F. Haven
}

MS. date: October 31, 1975

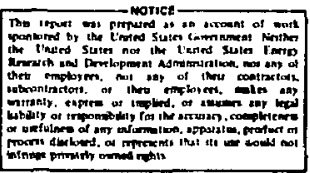

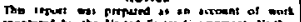

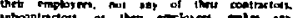

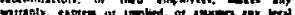

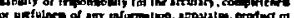

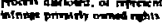




\section{Contenta}

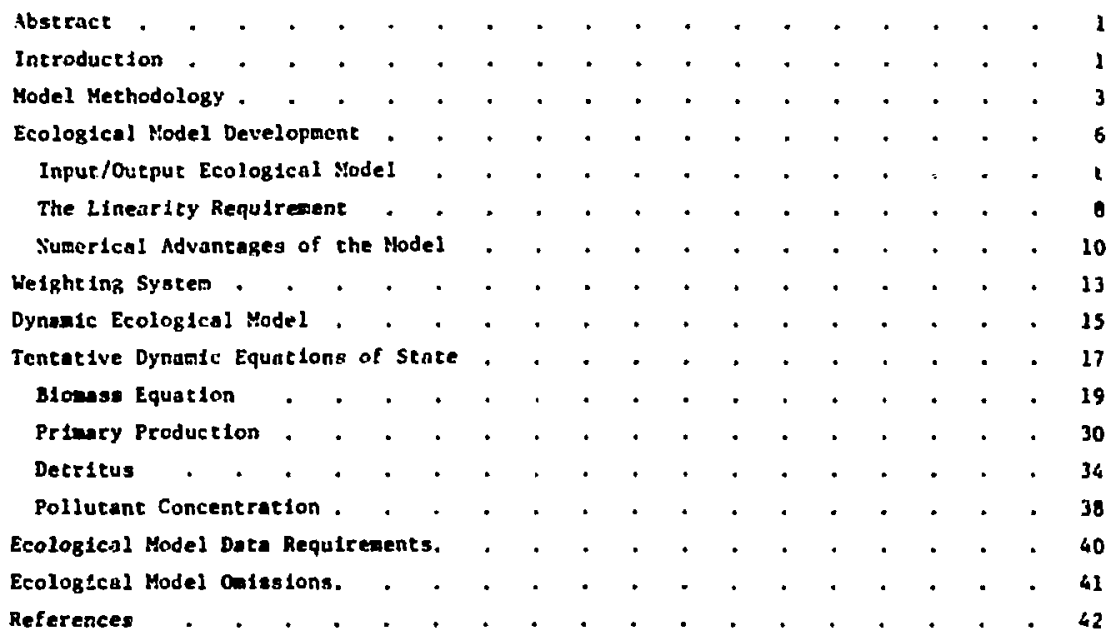




\title{
A METHODOLOGY FOR IMPACT ASSESSMENT IN THE ESTUARINE/MARINE ENVIRONMENT
}

\begin{abstract}
Abutract
lmacts on the estuarine/rarine cnvironment can be assessed in economic terms by tracing the tapict flose out of the ceonomic sector chrough the garine tenvi ronment and back into the conomic sector as changes in natural resource svallabllity. An lnpact can then be measurad by the changes created in the economic aector by changes in resource avallability. Primary emphasis is placed on the development of an appropriate

ecological model of the estuarine environwent for th1s purpose. Two types, an ecologicel inpuc/output model and a dynamic (difference equation) model, are propoged. Accoptabllity criterla for these wodels Include the abllity to track lethal and mubletha1, direct and Indirect (food web), and ahort- and long-term effects of a varlety of pollutante related to the production and use of varlous energy rescurces.
\end{abstract}

\section{Introduction}

The goal of this effore is to develop a methodulogy capable of assessing and cvaluating the fmpact of present and fucure energy-related inctivities on the marine/ eseuarine environment. For this purpose, an impact is defined as a change in either the quality or quanticy of a morine resource as the result of a given uction and the value of chat change. Thus 10 pacrs assectinted with energy-related activities will arise directly from the effluent londing of point and nonpoint discharges assoclated wth the generation and end use of the varlous forms of energy, and indirectly from the changes in other economic sectors induced by changes in energy-related indugtries and the increased effluent loading assoclated with thwe changes.

An overall concept for impact Identification and assessment in the estuarine environment is shown in Fig. 1 . In chis figure regional economic and iquatic ecological parameters are shown in an intrastctionsl input/output ( $1 / 0$ ) nintrix format, with incersectional transfer functions used to crangute flows between the two sections. This conceptual framework is a somcwhat simplified form of the more complete regional analysis framewcrk depicted 1j Fig. 2. This figure shows four general Intrasectional models with full interconnecting Intersectional transfer functions. The simplification from Fig. 2 to FIg. 1 is based on the following premises:

1. Pollutants introduced into the marine/escuarine aquatic environment w111 have a negliglble impact on human health, and thus that section can be disregarded.

2. Since there Is suff Ictent independence between the aquatic and nonaquatic environments, the aquatic environment can 


\begin{tabular}{|c|c|c|c|c|}
\hline & $\begin{array}{l}\text { Economic } \\
\text { sectors }\end{array}$ & $\begin{array}{c}\text { Physical, chemical, and } \\
\text { environmental } \\
\text { parameters }\end{array}$ & $\begin{array}{c}\text { Biotic } \\
\text { ecosystem }\end{array}$ & $\mathbf{R}$ \\
\hline $\begin{array}{l}\text { Economic } \\
\text { sectors }\end{array}$ & I/C Matrix & $\begin{array}{c}\text { Hydrological } \\
\text { dispersion and sediment } \\
\text { transfer }\end{array}$ & & \\
\hline $\begin{array}{l}\text { Physical, } \\
\text { chemical, and } \\
\text { environmental } \\
\text { parameters }\end{array}$ & $\begin{array}{l}\text { Woighting } \\
\text { system }\end{array}$ & $\begin{array}{l}\text { Ecolugical model } \\
\text { (dynamic or } \mid / 0 \text { ) }\end{array}$ & & \\
\hline $\begin{array}{l}\text { Biotic } \\
\text { ecosystem }\end{array}$ & & & & \\
\hline & & & & \\
\hline
\end{tabular}

F18. 1. Environsental/economic interaction concept.

\begin{tabular}{|c|c|c|c|c|}
\hline & Economic & Environmental & Human healrh & Social/political \\
\hline Economic & $\begin{array}{l}\text { Economic } \\
\text { intrasectional } \\
\text { model }\end{array}$ & $\begin{array}{c}\text { Economic } \rightarrow \\
\text { environmental } \\
\text { transfer } \\
\text { model }\end{array}$ & $\begin{array}{c}\text { Economic } \rightarrow \\
\text { human health } \\
\text { transfer } \\
\text { model }\end{array}$ & $\begin{array}{c}\text { Economic } \rightarrow \\
\text { social/political } \\
\text { transfer } \\
\text { model }\end{array}$ \\
\hline Environmental & $\begin{array}{c}\text { Emvironmental } \rightarrow \\
\text { economic } \\
\text { transfer } \\
\text { model }\end{array}$ & $\begin{array}{l}\text { Environmental } \\
\text { intrasectional } \\
\text { model } \\
\text { set }\end{array}$ & $\begin{array}{c}\text { Environmental } \rightarrow \\
\text { human health } \\
\text { transfer } \\
\text { model }\end{array}$ & $\begin{array}{c}\text { Environmental } \rightarrow \\
\text { social/political } \\
\text { trarisfer } \\
\text { model }\end{array}$ \\
\hline $\begin{array}{l}\text { Human } \\
\text { health }\end{array}$ & $\begin{array}{c}\text { Human health } \rightarrow \\
\text { economic } \\
\text { transfer } \\
\text { model }\end{array}$ & $\begin{array}{c}\text { Human health } \rightarrow \\
\text { environmental } \\
\text { transfer } \\
\text { model }\end{array}$ & $\begin{array}{c}\text { Human health } \\
\text { intrasectional } \\
\text { model }\end{array}$ & $\begin{array}{c}\text { Human health } \rightarrow \\
\text { social/political } \\
\text { rransfer } \\
\text { model }\end{array}$ \\
\hline $\begin{array}{c}\text { Social/ } \\
\text { political }\end{array}$ & $\begin{array}{c}\text { Social/political } \rightarrow \\
\text { economic } \\
\text { transfer } \\
\text { model }\end{array}$ & $\begin{array}{c}\text { Social/political } \rightarrow \\
\text { environmental } \\
\text { transfer } \\
\text { model }\end{array}$ & $\begin{array}{c}\text { Social/political } \rightarrow \\
\text { human health } \\
\text { transfer } \\
\text { model }\end{array}$ & $\begin{array}{l}\text { Social/political } \\
\text { intrasectional } \\
\text { madel }\end{array}$ \\
\hline
\end{tabular}

F18. 2. Reglonal Impact analysis framework. 
be studied in a separate regional analysis.

3. Effects in the social/political sector can be externalized in the form of scenartos and thus need not be internalized within the model.

Let us look first at the intersectional portion of Fig. 1. The economic sector I/O model has been widely used for economic regional analysis for a number of years (Isard, 1972; Stoenener et al., 1972; Kunin et al., 1975). All outputs listed as products from the varlous economic sectors are reconsumed by ather sectors or exported outside the model area (column Y), so that the output flow from the economic sector Into the environmental sector consists entirely of waste flows. Aqueous waste flows (the sole concern of this study) are transported into the local ecosystem through water-colum advective pollutant dispersion and sefiment transport. The environmental sector can be viewed as being very :ımilar to the economic sector. Each element (environmental parameter, pollutant, or taxon) transfers a portion of its output biomass through food-web transfers or pollutant uptake to some other sector element (caxon). Again all products are consuned by other elements within this sector or are exported outside the model limits. The flow from the environmental sector back into the economic sector is made up of the natural resources used as imputs to the various economic sectors. From estuarine and coastal zone waters this list of resources includes flsh and other edible products, cooling and cleaning waters, salt, sand, gravel, transportation and recreational media, waste-assimilative capacity, and so forth.

Once this entire system has been modeled, an Impact analysis can be performed as follows: An action to be studied (e.g., inclusion of a new industry or activity, or an lucrease in an existing one) is inserted into the economic sector $I / 0$ model and allowed to perturb that model. The resultant change in total effluent flow is then transmitted Into the ecosystew model through the hydrodynamic, Aispersion, and sediment-transport models. The change in sector effluent Input is then allowed to perturb throughout the ecosystem model. A weighting system, which will be discussed In more detall later, is then applied to the resulting changes in natural-resource avallability to measure the impact on the local economic sector of these resourceavallability changes. The total value of this latter Impact is, then, the value, or an assessment, of the original action's impact on the aquatic environment.

\section{Model Methodology}

A functional methodology for the development of the ecological model and two transfer functions listed in Fig. 1 is shown in Fig. 3. The desired characceristics of tłis methodology include the following:
1. An ability to assess pollutant inpacts, including both lethal and sublethal, direct and indirect.

2. A segmented "block" design to allow creation and use of each segment individua11y. 


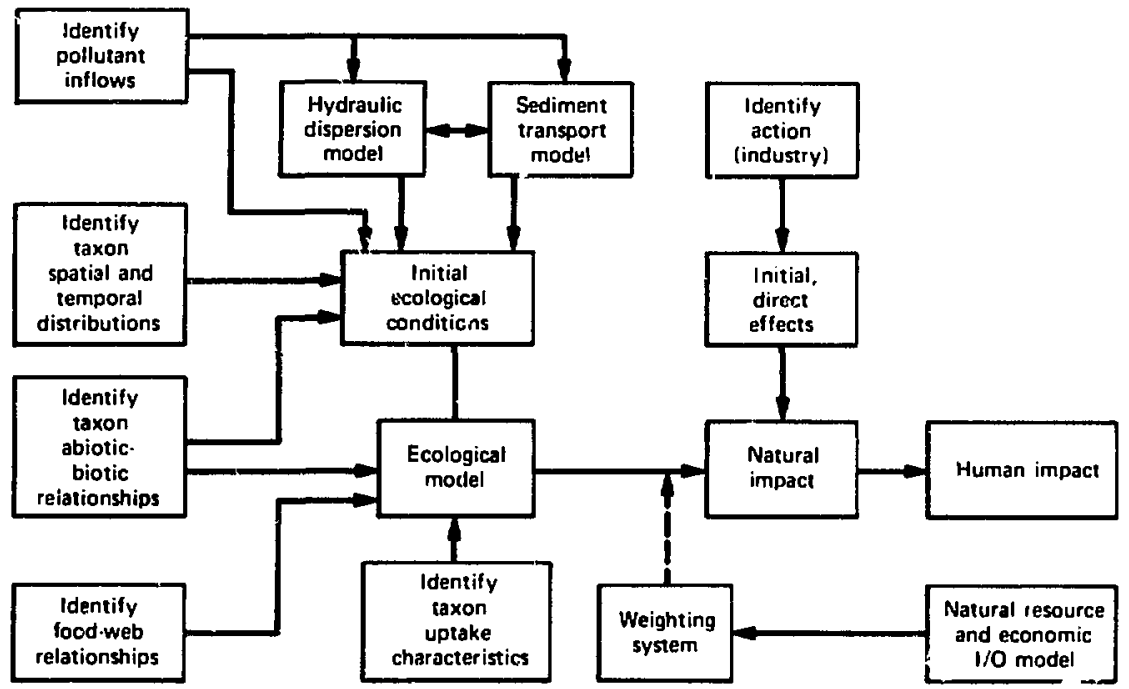

F18. 3. Nethodology for San Francisco estuary lapact anelysis.

3. The ability to readily incorporate results of future resesrch into any segment.

4. The ability to use all model segments with existing incomplete data and still obtain meaningful results.

The econcmic section I/O model is not included in this methodological diagram except for the identification of sector effluent flows.

In order to better comply with characteristic 4, a somewhat limited methodology has been developed. The complete methodolcgical approach would require intial inclusion of food-web relationships in all bay segments over all seasons and of the uptake characteristics and toxic effects of all known toxins entering the bay. The limited methodology is designed to 11 mit food-web consideration spatially and temporally, and to focus attention on a cortain group of effluent pollutants assoclated with a given action or industry.

As stown in Fig. 4, this 11 mited plan first requires the identification of an Industry for consideration (1.e., petroleum refining, hydroelectric, etc.). Transport and dispersion models are then run, first with all known effluents and second without the effluents associated with the given industry. A comparative analysis of these two runs will reveal the areas, seasons, and specific pollutants for which this industry has a discernible effect on water quality. The ecological model then need only be structured for those specific areas, seasons, and pollutants. Within these limitations the ecological model 


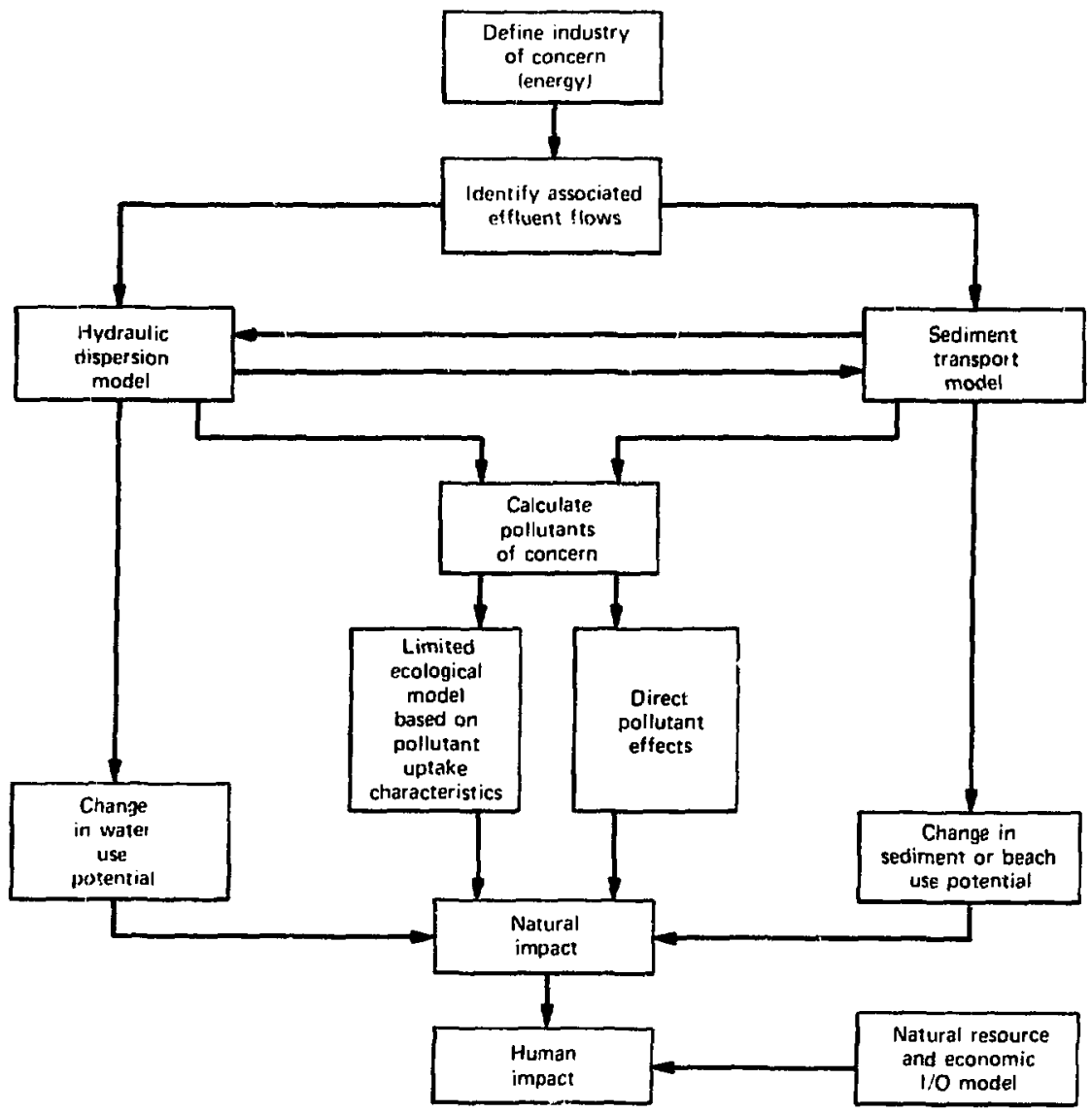

F1g. 4. Limited-scope methodology for San Franclsco eatuary topact analysis.

itself will be as complete as the more general model and will have all of its analytical capabilities. Thus the use of either methodology for any given spectitc action or industry should yfeld an idenctcal impact assessment. The difference is in model construction and run time.
This brevity is gained at the cost of an additionai model assumption--namely, that the mortality and behavior of the taxa included in the model food wab are not dominated by factors external to the limfted model (i.e., pollut.ants not associated with this industry) and that these 
taxa w11 respond to changes in the modeled pollutants in a predictable way.

The long-range goal of this study is to develop the general methodology.
Whether or not this additional assumption associated with the incerim use of the Ifmited methodology rill prove troublesome is not yet known.

\section{Ecological Model Development}

There are several hydrodynamic and disperuion models for the San Francisco Bay system, the first developmental area for this methodology (Chen and Orlob, 1975; Nelson and Lerseth, 1972; Water Rersources Englneers, Inc., 1965). There has aiso been substantial documentation of bay sediment movements (Enstein and Krone, 1961; U.S. Army Corps of Engineers, 1975, Appendices $F$ and $I)$, and more study is currently under way at several locations.

As a result, the princifal effort of this study is the ecological model development. It is desired to keep this mod 31 as simple as possible without losing the ability to track pollutant buildup, pollutant effects, and the impact on the ecosystem of those effects. Two types of ecological wodels are currently belng considered, both based on a food-web submodel. As with the ecological rodel as a whole, the goal here is to reduce the number of taxon entries actually included in the food-web model as far as possible by generalizing the species and famllies included within each taxon entry. The limiting criteria tentatively planned for this simplification process are as follows:

1. All included species must occupy a similar position within the local food web (same sources, same predators).

2. All included species must display similar or complementary spatiai or temporal distribut lons.
3. All Included spectes must demonstrate gimlar uptake characteristics for all toxIng modeled from each toxin source (food, water colums, sediments).

4. Fach taxon must represent a olgnificant element within the bay ecosystem.

The desirability of this simpliftcation process is rooted in this study's concept that an ecosystem is not an impact analysis end point but rather a transmiasion path of the Impact flow.

INPUT/OUTPUT ECOLOGLCAL MODEI.

Two Lypes of ecological godel are currently being considered:

1. Input/output model (designed for direct compatibility with the rest of the full methodological submodels).

2. Dynamic molel (using finite differences and differential equations to track the rapid variation in water quality and taxon populations common in an estuarine environment).

An I/O model concept is shown in FIg. 5 . In accual operation mass transfer (1nd1cated by an $X$ ) would be shown in a quant1tacive forn derived from the mass balance of the food web. Direct pollutant and nutrient uptake from both sediments and the water column can be simultanteously entered. Environmental parameters (temperature, salinity, turbidity, etc.) can be entered as time-step negative mass 
transferc intw the taxa based on the ligal subopt ima! ity of chat parameler at a aiven t the scep and its negat ive ffect an iveral! taxa biomests and taxi act lutsy fresplration increases, feedlag reduction, tortaitty insteases, etc.j. Once an initial steady-state condition matrix is $\therefore$ reated. perturbations from that equflibrium cundil lun ciln be Insered inter one ir more syslem paranterets, and theit iotal impact on the ecougstem can be measured by teohntques to bo discussed later in this saceloth.

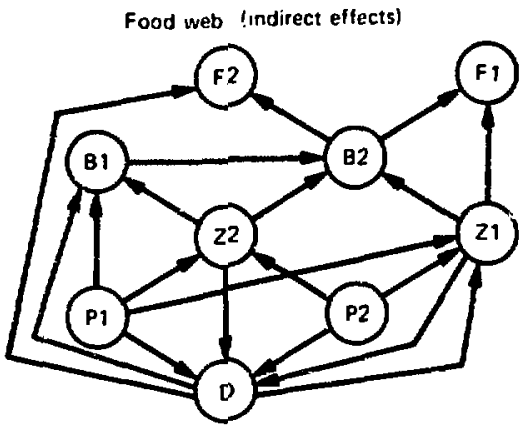

1/O Model (direct effects) $|\mathrm{P} 1| \mathrm{P} 2|\mathrm{Z1} 1| \mathrm{Z2} 2|\mathrm{~B} 1| \mathrm{B} 2|\mathrm{~F} 1| \mathrm{F} 2 \mid$ Export

\begin{tabular}{|c|c|c|c|c|c|c|c|c|c|}
\hline Light & $x$ & $x$ & & & & & & & \\
\hline Nutrients & $\bar{x}$ & $x$ & & & & & & & \\
\hline Temperaturo, etc. & & & & & & & & & \\
\hline Pollutant 1 & & $\mathrm{x}$ & $\bar{x}$ & & & $\bar{x}$ & $\underline{x}$ & $\bar{x}$ & \\
\hline Pollutant 2 & $\bar{x}$ & & $x$ & $\bar{x}$ & $x$ & $x$ & & & \\
\hline $\mathbf{P 1}$ & & & $\underline{x}$ & $\underline{x}$ & & & & & $x$ \\
\hline $\mathbf{P 2}$ & & & $\underline{x}$ & $\underline{x}$ & & & & & $x$ \\
\hline 21 & & & & & & $x$ & $x$ & & $\bar{x}$ \\
\hline $\mathbf{2 2}$ & & & & & $x$ & $x$ & & & $\bar{x}$ \\
\hline B1 & & & & & & $\bar{x}$ & & & $\bar{x}$ \\
\hline B2 & & & & & & & $x$ & $x$ & $x$ \\
\hline $\mathbf{F 1}$ & & & & & & & & & $\underline{x}$ \\
\hline $\mathrm{F2}$ & & & & & & & & & $x$ \\
\hline import & & & $\bar{x}$ & & $x$ & & & $x$ & \\
\hline
\end{tabular}

FIg. 5. Exological model 1.
The prinispal advantages of this model Inelude the following:

1. An $1 / 0$ analysis y lelds a numericai value for lie relati: Impact of unte

aroges in each eiement on the entire ecosystem.

2. An $1 / 0$ format for the ecolog $1 \mathrm{ca} 1$ sector would he directly compatible with both the methodology and the format of the cconomic sector mudel and with the weighting system model. With thls format, each element of the ecosystem could be assigied i) slngle numerical coefficlent reflecting the value to the loc'l economy of the impact on the entire ecosystem of unit changes In that element from some intelal steady-state condition caused directly by changes, or artions, in the local cconnmy. This could he 3 powerful decision-making tool.

3. The I/O format can produce a good approximation of small changes from an intially modeled condition.

However, there are also four important IImt tations on the use of an I/O ecological mode1:

1. Spatial homogeneity of each species throughout the region modeled is assumed. An I/O model is not a point model, but rather an area model. Thus most subregional Impact definition ts Iost. This is rarely critical if the enfire $I / O$ analysis is confined to a limited spatial area such as an Indj.vidual estuary or segment of coastline, but it can prevent the application of the model on a large scale.

2. An I/O analygis is not particularly compatible with a time-step progression anglysis. The I/O matrix cannot easily be revised and updated at each time step without loss of much of its meaning. 
3. For the point in time established as the base, or initiai, condition that is refiected in the initial model, all mode1 parameters must be known. Taxa biomasses and internal pollutant concentration are the most critical of this set of required information; however, these are rarely, if ever, known for a large estuarine system like San Francisco Bay.

It does not appear to be as much of a limitation outside the highly variable estuarine environment.

4. An $I / 0$ analysis ts linear. This does not require that abiotic-biotic relationships or caxa pollutant uptake rates be 11near; however, it does requize that, once an infial-condition point on a curvilinear relationship has been estabIlshew and put into the I/O matrix, changes from that condition bi: Linear.
THE LINEARITY REQUIREMENT

Within the framerork of this study the linearity requirement is much easier to live with than is normally supposed. Foodweb consumptive transfers do tend toward linearity. With the addition of eertain control criteria, the inclusion of non11near abiotic-biotic transfer relationships with the I/O matrix can be limiced to those that can be closely approximated by linear change. This limiting-factor criterion is diagrammatically 11 lustrated in Fig. 6. The principle involved in the criterion is the analysis of the present, or initial, condition and each resulting abiotic-biotic relationahip to determine (1) wherher each blotic taxon and its ablotic-biotic relationships would be entered into the $I / O$ matrix and (2) whether changes Erom this position cuuld be 11nearly approximated by $1 / 0$ procedures.

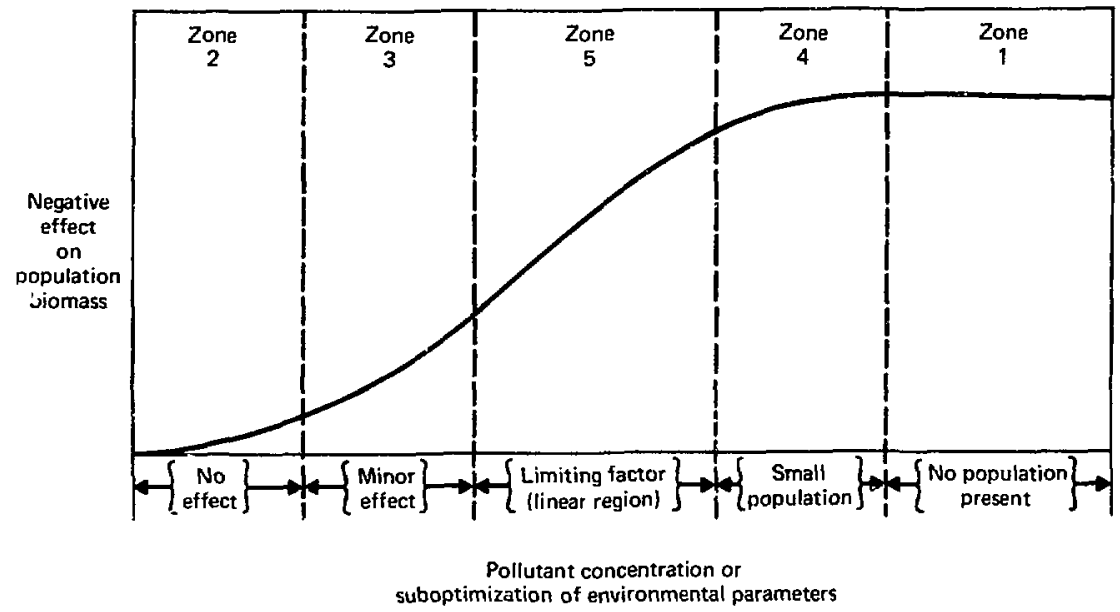

Fig, 6. Graphical representation of $11 \mathrm{mlt}$ ing-factor concept. 
Figure 6 relates the most typical curviline ir relationship between deviatiun from optimal. conditions for environmental parameters and for pollutant concentrations, and the resulting negative impact on taxon biomass. Although other characteristic curve shapes are possible, the limitind-factor analysis remains the same. Figure 6 identifies five zones within which the nitial-condition relationship could 1i. . i i zones can be defined as follok's:

Zone 1 (maximum effect). In general, the maximum deleterious effect of any poljutant corresponds with taxon elinination. As a result, neither this taxon nor this abiotic-biotic relationship should appear in the $1 / 0$ matrix, since the taxon w11 not be entered in the inttialconditicn food web.

Zone 2 (no effect). This corresponds closely with taxon optimum environmental conditions and with near-zero pollutant concentrations. Inclusion of these relationships in the matrix can be prevented by identification of environmental response and by setting an arbitrary minimum po1lutant concentration for consideration. One possible approach is to tie this minimum to the known LDSO levels for each taxon by using, for example, 'T $D_{50}$ )/1000 as a minimum concentration for consideration.

Zone 3 (smal1 population). It is anticipated that pollutant populattons and environmental parameter populations that fall within this range can be initlally omitted through the taxon inclusion criteria, especially through criterion 4 (see page 6). If existing conditions are such that a given population has been so suppressed by the action of an existing pollu- tant that the relationship between that pollutant and that taxon falls within this nonlifear range, then that population should be so small that it will not be included as a separate taxon. This taxon will then be ircluded into some more genera1 taxon where the nonlinear effects of this particular relationship should be mintmized. Though this will not guarantee elinination of all such relationships, it will minimize both thelr number and their 1mportance.

Zone 4 (minor effect). The only available means of excluding zone 4 from the linear $1 / O$ table is by careful selection of the pollutant concentrations and enviranmental paraweter limit.s mentioned under zone 2. This selection wi11 be based on the result of an ongoing literature search.

With these four zones essentlally excluded, all relationships, or transfers, listed in the ablotic-blotic section of the ecosystem I/O model should fall within the fairly linear region labeled zone 5 . It stould also be noted that relationships within this region are those of prime concern. No single action or industry wiIl create extremely large changes in the physical/chemical environmental quality in a large estuarine or marine system (such as San Francisco Bay, Long Island Sound, or Chesapeake Bay). This near-11near region is the area in which relatively small changes in total pollutant concentration will create the largest changes in the blotic comanity.

A flag system will have to be incorporated into the overal' ecological model to compare the position of each physical/ chemical pollutant parameter to its "allowable" range of values at each time step. Should any parameter transgress the bounds 
of this linear range, al1 transfers based on that parameter will require appropriate modification or matrix exclusion, as appropriate.

NUERICAL ADVANTAGES OF THE MODEL

Having established that I1nearity is an acceptable limitation over relatively small intervals of change even within a n.ulinear system, such as a complex ecosystem, we can now discuss the numerical advantages of this model. Similar procedures, using one of the control methods discussed below, have been used in ecological modeling by Isard and his discussions (Isard, 1960, 1972) are referenced as a more thorough coverage of the basic numerical techniques.

Transfers irom the supply $\left(x_{i}\right)$ side of the ecological 1/0 matrix to the demand or consumer side $\left(x_{j}\right)$ can be analyzed in three ways.

1. Transfers ray be demand controlled. This type of traisfer, which is the normal economic sector sontrol mechanism, spectfies that the mass of a transfer $\left(x_{1 j}\right)$ is proportional to the demand or to the blomass of the consumer taxon $\left(x_{j}\right)$. Thus the analytical element of concern is the amount of transfer per unit consumer blomass $\left(a_{1 j}=x_{1 j} / x_{j}\right)$. Th1s type of transfer controi is found ecologically only when food supplies are large in comparison to the consumer pass (as with a plankton "bloom").

2. Transfers thay be supply controlled. The normal assumption of an ecological food web is that the mass of each species is food limited. This transfer control is then the basic ecological control of concern, and the appropriate analytical element is the mass transfer $\left(x_{1 f}\right)$ per unit mass of food supply $\left(x_{i}\right)$, or $a_{i j}=x_{i j} / x_{i}$.

3. Transfer control may be unspecified In a near-steady-state condition. The amount of blomass galned by any taxon as a result of feeding is then directly proportional to the anount of food consumed. Thus in a steady state (or near steady state), with transfers $x_{i j}$ held constant, the mass of each consumer taxon $\left(X_{j}\right)$ wi11 becotne proportional to the transfer mass 1tself. Here the element of concern is the consumer biomass per unit transfer, or $a_{1 j}=x_{j} / x_{i j}$.

Al1 prevlous work located used the first, or normal, econonic control mechanlsm (Isard, 1972), and the seemingly more applicable ecologital control mechanisms (tyfes 2 and 3 ) appear to be conceptual innovations of this study.

Mathematically the matrix analysis based on any of these control mechanisms Is identical, and the resulting equaiions are Identical in Form. What will change is the numerical value of the elements of the $\overline{\bar{A}}$ matrix reflecting variations in system sensitivity to changes in the availability and demand of a given taxon with changes in the control Inechanism of its transfers.

The fundamentals of this potential analysis are shown in $F I_{g} \cdot 7$. Here $X_{1}$ can be defined as the blomass of each taxon at time step $t$ and $x_{1}$ as the biomass of each taxon ut time step $(t+1)$. This latter definition is not entirely accurate, as taxon $x_{j}$ assimilates into new biomass only a small fraction (about 10\%) of 1ts total consumption $\boldsymbol{\Sigma}_{\mathbf{i}} \mathbf{x}_{1 j}$. Therefore $x_{j}$ in the I/O matrix literally represents the mass available to taxon $x_{j}$ for conversion into 
new taxon mass. Once this conversion has been completed, the resulting biomass becomes $x_{i}$ for the subsequer: time step,

The export term on Fig. $?$ can be defined as the sum of all mass and energy leaving $x_{i}$ and not being consumed by some other element $x_{j}$ within the model. This term then includes advective export, mi-

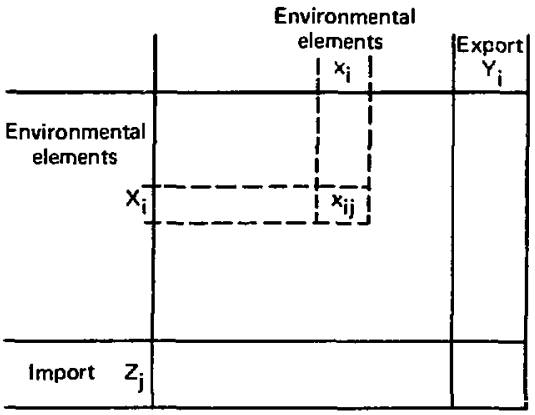

Approach 1:

$a_{i j}=\frac{x_{1 j}}{x_{j}}, \quad a_{1 j}=\frac{x_{1 j}}{x_{j}}$, or $a_{i j}=\frac{x_{j}}{x_{i j}}$,

depending on transfer control, and

$x_{i}=\sum_{j} x_{j} a_{i j}+Y_{1}$ or $\sum_{j} \frac{x_{j}}{a_{i j}}+y_{1}$

as appropriate.

Approach 2:

For steady-state conditions, $X_{1}=X_{j}$ for $1=j$ and for the nth element

$\sum_{j} x_{n, j}+y_{n}=\sum_{1} x_{1, n}+z_{j}$

or

$\sum_{1, j(i=j)}\left(x_{n, j}-x_{1, n}\right)=z_{n}-Y_{n}$

F1g. 7. Input/output analysis methodology. gration, respiration, excretion, and natural nortality unless soine or all of these terms are internalized within the model. The 1mport $j$ term can similarly be defined as the sum of all mass and energy consumed by some element $x_{j}$ within the model that does not come direct'y from some other element $x_{1}$ within the model system.

With these definitions, $x_{1}$ can be expressed as follows:

$$
x_{i}=\sum_{j} x_{1 j}+y_{1}
$$

Substituting, we obtain

$$
\begin{aligned}
& X_{1}=\sum_{j} x_{j} a_{1 j}+Y_{1}, \\
& x_{1}=\sum_{j} x_{i j} a_{i j}+Y_{1},
\end{aligned}
$$

depending on the control mechanism used (i.e., depending on the definttion of $\left.a_{i j}\right)$.

As discussed by Isard (1960), this can be expanded to

$$
\bar{X}=\bar{X} \overline{\bar{A}}+\bar{Y},
$$

or

$$
\vec{X}=(\overline{\bar{I}}-\overline{\bar{A}})^{-I} \bar{Y},
$$

where $(\overline{\bar{I}}-\overline{\bar{A}})^{-1}$ is called the inverse matrix and evaluates the impact of unit changes in elther supply or demand of one element on the entire system.

The impact of unit changes in the aval1ability of one or more system elements, which Is the focus of this study, can now 
be evaluated as follows: irpact of unte changes $\operatorname{In} \mathrm{x}_{1} \equiv \operatorname{Imp}_{1}$,

$$
\operatorname{ImP}_{i}=\sum_{j}\left(i_{i j}-a_{1 j}\right)^{-1} \text {. }
$$

The impact on an ecosystem of some external action is then

$$
\begin{aligned}
\text { impact } & =\sum_{i} \Delta x_{1} \operatorname{Imp}_{i} \\
& =\sum_{1} \Delta x_{i} \sum_{j}\left(1_{1 j}-a_{i j}\right)^{-1} .
\end{aligned}
$$

Defining $\overline{\bar{M}}=(\overline{\bar{I}}=\overline{\bar{A}})^{-1}$, this can be rewritten as

$$
\text { impact }=\sum_{i} \Delta x_{i} \sum_{j} \mathfrak{m}_{i j} \text {, }
$$

where $\Delta x_{i}$ is the magnitude of the inttial change in the availability of each system element, $x_{i}$, as defined by the change in effluent flow and the first intersectional transfer function.

The second analytical approach available assumes at least a temporary steady-state condition within the ecosysten (see Fig. 7). Under this condition, the taxon blomass will remain constant over any time interval and $x_{i}=x_{j}$ for $t=j$. We know that

$$
x_{i}=\sum_{j} x_{1 j}+y_{i}+R_{i}
$$

and

$$
x_{j}=\sum_{i} x_{i j}+z_{i},
$$

where $R_{1}$ is energy export by respiration $\left(R_{j}=0\right.$, as no taxa except primary producers directly 1mport energy, and this energy term will bo internalized). Hence an equality can be established for the nth element as

$$
x_{n}^{i n} \equiv x_{j},
$$

$$
x_{n}^{\text {out }} \equiv x_{1}
$$

and

$$
\sum_{1} x_{1, n}+z_{n}=\sum_{j} x_{n, j}+Y_{n}+R_{n}
$$

Expanding, we obtain

$$
\begin{aligned}
& \left(x_{1, n}+x_{2, n}+\cdots+x_{m, n}\right)+z_{n} \\
& \left(x_{n, 1}+x_{n, 2}+\cdots+x_{n, m}\right)+y_{n}+R_{n},
\end{aligned}
$$

and on rearrangling we find that

$$
\begin{aligned}
& \sum_{i, j(\text { for } i=j)}\left(x_{n, j}-x_{1, n}\right) \\
& =z_{n}-Y_{n}-R_{n} .
\end{aligned}
$$

Now substituting for $a_{1 j} \equiv x_{j} / x_{1 j}$ for a steady-state systen, we get

$$
\sum_{i, j(\text { for } i=j)}\left(\frac{x_{j}}{a_{n, j}}-\frac{x_{n}}{a_{i, n}}\right)+R_{n}=z_{n}-y_{n} \text {. }
$$

In this equation several noteworthy concepts are included:

1. The quantity $z_{n}-Y_{n}$ is the net mass 1mport of the nth element in the ecosystem. This gives an indication of which taxa tend to introduce new substances (such as recently released pollutants) tnto the local 
ecosystem food web and wich will tend to export such existing substances out of the local system.

2. The term $x_{j} / a_{n, j}$ measures the impact of unte changes in the mass transfer from $n$ to the rest of the local ecosystem.

3. The term $x_{n} / a_{1, n}$ measures the impact of unit changes in the mass transfer into $n$ from the rest of the iocal ecosystem.

4. The term

$$
\sum_{i, j(\text { for } i=j)}\left(\frac{x_{j}}{a_{n, j}}-\frac{x_{n}}{a_{i, n}}\right)
$$

ther measures the net system impact (or importance) of the nth element, fncludirg the fimportance to the rest of the ecosystem of transfers into and out of that element.

While both of the analytical models discussed above show potentlal value for elucldating the sensitivities of a system, the first is better able to express the total impact of an economic action and is also more compatible with the other elements (economic sector $I / O$ matrix and weighting system) of this impact analysis concept.

\section{Weighting System}

The weighting-system model will be discussed next because o: its direct design compatibility with the I/0 ecological model. The purpose of any weighting system is to apply various temporal and spatial perspectives to the changes in resource avallability identifled by the ecological model. The use of tiese vartous temporal and spatial persfacilyts Ishort-term, long-term, bay segment, entire bay, Cullfornia, or western United States) will allow full evaluation of the significance of identified resource changes. Long-term evaluations may be based on such parameters as community scab1lity, resilLence, changes in primary elemental cycling patterns, and changes in taxon diversity. Short-term Impacts will be measured by the interaction of these resources with the economic sectors. The spatial zone of concern for this analysis w111 be defined by local economic boundarles. For San Francisco Bay, this is most of the ninecounty area around the bay.
The weighting system designed for this analysts is shown on Fig. 1 as the final intersectional transfer for the impact flow pathway. Its purpose is to apply to the environmental impacts identified by the ecological model a value that can then be used as an impur to the decision-making process. The value concept chosen is the value each element of the ecosystem obtains as a natural-resource input to the local economy. This evaluation can be accomplished by establishting a transfer matrix for marine natural renources to various economic secto:s. This transfer matrix Is Identical with an I;O matrix, except that it records transfers in only one direction. While an $1 / 0$ matrix reflects transfers from each sector to and from each other sector, a transfer matrix shows only transfers frow one set of sectors to sowe other set without Indicating the return flow.

For the purposes of this mode1, a transfer matrix is constructed showing mass 
transfers from each element of the natural environment wco each sector of the local economy. By using the demand-controlledtransfer mathematical techniques mentioned earlier, this matrix can be made to yleld the relative impact of unit changes in the avallabllity of each Individual resource on the economy. In order to better represent a true value estimation, each economic sector is weighted by the total dollar value output of that sector. Thus the weights obtained reflect the relative dollar value of unit change in the aval1ability of each resource. These weights can then be applied to changes in taxon avallabllity and water quality revealed by the ecologlcal model to obtain a relative dollar value for the impact on the natural environment of specified industrles or actions within the local economy. The matrix format for this welghting system is shown in Fig. 8.

Industries using natural resource inputs (listed by SICs)

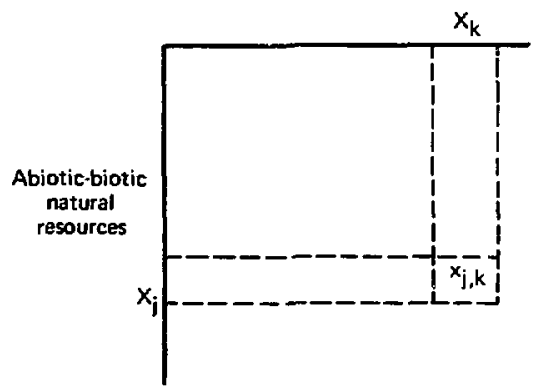

Fig. 8. Impact welghta. Here aj,k $=x_{y}, k / x_{f}=$ quantity of 1 th resource used per unft product of the kth economic sector.
Sumeicai uperativiss with the addition of a weighting factor are as follows:

$x_{j}=\sum_{k} x_{j, k}+y_{j}=\sum_{k} x_{k} a_{j, k}+y_{j}$,

where

$$
\begin{aligned}
a_{j, k}= & x_{j, k} / x_{k}, \\
x_{j, k}= & \text { mass of resource } j \text { used in total } \\
& \text { production of product } h, \\
x_{k}= & \text { total resource consumption by } \\
& \text { the kth econotic sector, } \\
Y_{j}= & \text { amount of resource } j \text { not } \\
& \text { harvested, } \\
x_{j}= & \text { total mass of resource } j \text { as } \\
& \text { calculated by the ecologlcal } \\
& \text { model, } \\
Y_{k}= & \text { nonnatural resource factor inputs } \\
&
\end{aligned}
$$

This can be processed to the point where

$$
\bar{X}=(\overline{\bar{I}}-\overline{\bar{A}})^{-1} \bar{Y}
$$

The value of the tmpact of unit changes in the availability of $x_{j}$ can now be given as

$$
\operatorname{Imp}_{j}=\sum_{k}\left(k_{j, k}-a_{j, k}\right)^{-1} w_{k},
$$

where $w_{k}$ is the output dollar value or value added of sector $k$.

This impact can be defined as the value welght of the 1 th element in an ecological 
model based on the value of that element to the local economy, or

$$
w_{j}=I m p_{j}=\sum_{k} m_{j, k} w_{k} .
$$

This weight can now be inserted into Eq.

(5) as a weight acting on $\mathrm{m}_{i, j}$, so that the total value impact of an action in the economic sector can now be given by

$$
\text { impact }=\sum_{i} \Delta x_{1} \sum_{j} m_{i, j} w_{j} \text {, }
$$

or

impact $=\sum_{1} \Delta x_{1} \sum_{j} m_{1, j} \sum_{k} m_{j, k} w_{k}$,

where $i$ denotes all elements $\left(x_{1}\right)$ of the ecologlcal model measured on the supply side of the matrix, $j$ denotes all elements $\left(x_{j}\right)$ of the ecological model measured on the demand side of the matrix and simultaneously all elements on the resource- supply side of the weighting-system matrix, $k$ denotes all economic sectors ilsted by SIC codes, and $m_{i, j}, m_{j, k}, w_{k}, \Delta X_{i}$ are as previously defined.

Equation (13) traces the impact flow and the value of that impact from the effluent in the economic sector through the environmental sector and back to the economic sector based on changes from an Initial steady state. It 15 apparent that this type of predictive information has the potential to be a powerful decisionmaking tool.

It should be noted that by defining $\Delta x_{1}$ as the quality or avallability of ecological element $x_{i}$ after the economic activity under analysis minus that before the activity, net reductions in the qualitv or quantity result in numerically negative impact. Conversely, increases in resource availability result in positive impact. Thus this methodology for impact assessment will track both the relative magnitude and the direction of an 1mpact.

\section{Dynamic Ecological Model}

The first three limitations listed for the I/O ecological model may prove to be prohibitively limiting when applied into an extremely dynamic estuarine environment. Environmental parameter gradients may be too steep and changes in gradient slope too rapid for application of the I/O model. Furthermore, taxon variation Is much wider and the food web is generally less structured in an estuarine environment (Green, 1968; Lanff, 1967; McLusky, 1971; Perkins, 1974). As a result, a dynamic ecological model is being developed. Its position and function within the overall assessment concept will be Ident1cal with those of the $1 / 0$ nodel; however, the dynamic model will consist of a set of dynamic fintte-difference equations that w111 be discussed in deta11.

A schematic diagram of the dynamlc model is shown in Fig. 9. Initial hydrological, dispersion and sediment-transport models are identical with those previously mentioned. Innovations included in this approach are the following:

1. Where taxon Inclusion criteria allow, separation of larval and juventle 


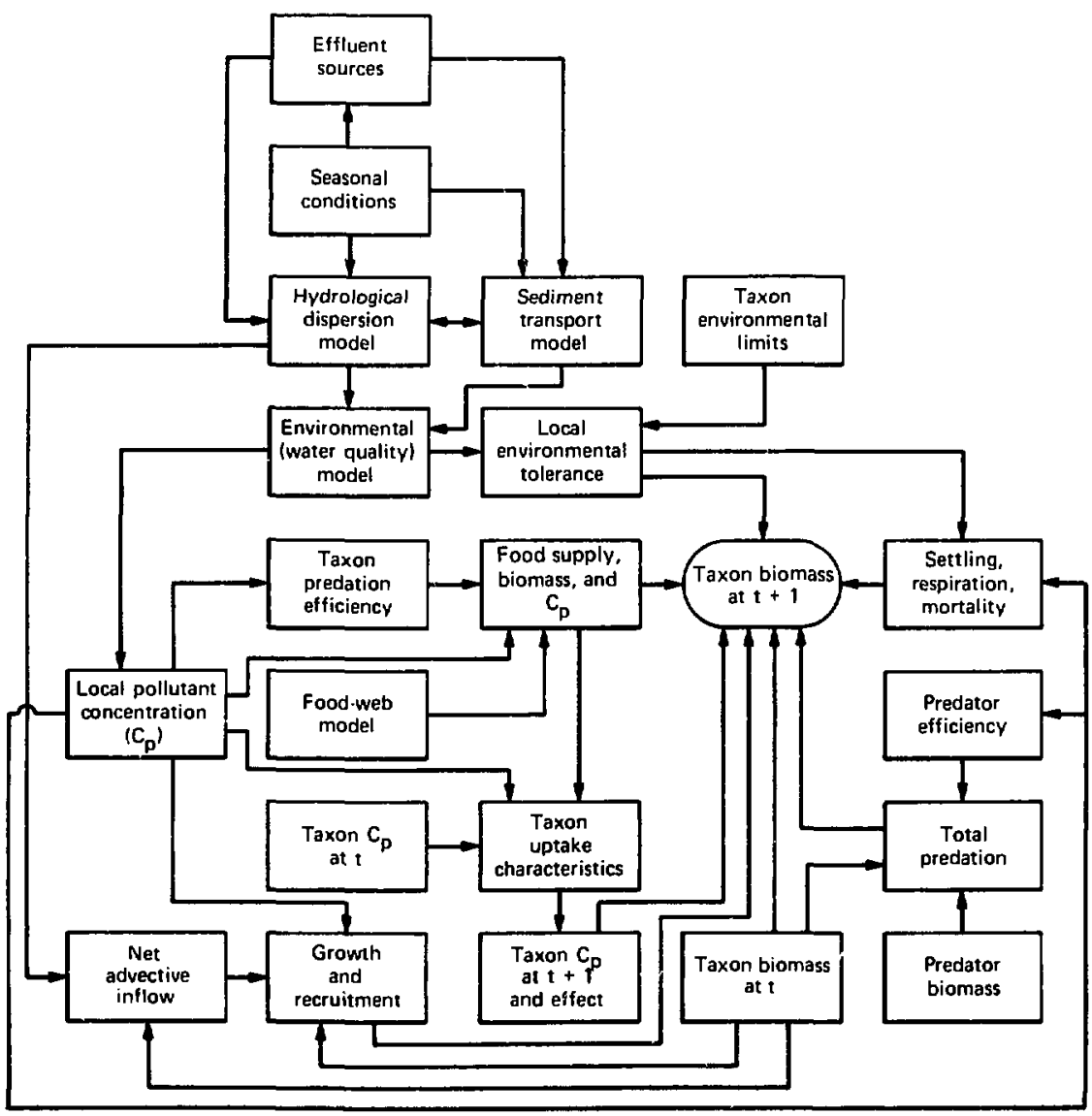

F1g. 9. Ecological model for San Franc18co estuary.

stages from adult stages with the inclusion of a recruitment term in the biomass equation. Th1s allows differentiation of pollutant-uptake races by larvae and by adults, differentiation of larval and adult reactions to $\mathrm{g}$ iven pollutant concentrations, and deletion from the feeding and predation terms of the biomass equation of a "fudge factor" parameter used to characterize changes in feeding habits and rates as a function of mean taxxon age.

2. Incluston of local phystcal/chemical envirunmental tolerance/preference on local biomass. This influence will be felt pri- 
marily in the "mlgration/advection" term in the bionass equation and secondarily in the mortality, respiration, and feeding terms.

3. Inclusion of other thar lethal pollutant effects in other than the mortality term of the biomass equation. As indicated in Fig. 9 , pollutant effects will be included in a number of the biomass-equation terms.

With these additions the dynamic model will consist of difference equations for primary production, detritus, and taxon biomass and differential equations to track pollutant concentrations within each taxon. This ecological model, as designed, cor- rects all limitations 1isted for the $1 / 0$ mode1, with the creation of only one new disadvantage. In most areas more initial data is required for the dynamic model, especially for model paranetrizacion. It must be noted, however, that actual masstranster data for food-web links is not required. This information is generated by the 'jlomass equation.

It is still a goal of this mode1development effort to simplify each equation and term as far as possible and still provide adequate transmisston of the Impact flow. An attempt is being made to reduce and externalize each term not closely associated with impact transmission.

\section{Tentative Dynamic Equations of State}

The remainder of this paper is devoted to a discussion of the tentative form of each of the principal iynamic model equacions. This developmental effort is neither flnalized nor complete, and this presentation is designed primarily to indicate the direction it is antizipated these equations will take.

As stated, there will be four basic state equations in the dynamic ecological model. These are the blomass equation, internal pollutant-concentration equation, detritus equation, and phytoplankton or primary production equation, shown in thelr conceptual form in FIg, 10. Before the tentacive equational form of each of these Is detailed, the general subscript plan should be defined. Three subscripts can be applied to any term: a taxonIdentification subscript, a time-step subscript, and a spatial, or node Identificurion, subscript. Temporal subscripts used are limited to either the past time step ( $t$ ) or the time step being currently analyzed $(t+1)$. Three separate subscripts will be used in association with each of the spatial and taxonidentification system:

\section{Taxon identification:}

1 Indicates the taxon that is under analysis or whose blomass is currently being calculated.

$j$ indicates a predator taxon--either all predators of taxon 1 or of all prey taxa k.

$k$ Indicates a food source, or prey, taxon-either all prey of taxon 1 or all prey of a general predator taxon $f$.

\section{Spatial identification:}

Q Indicates the node at which analysis is currently being conducted. 


\section{BIOMASS:}

$$
\begin{aligned}
\text { Biomass }_{\mathrm{t}+1}= & \pm \text { recruitment } \pm \text { advection }+ \text { biomass } \\
& - \text { respiration }- \text { predation }- \text { mortality })
\end{aligned}
$$

2. PRIMARY PAODUCTION:

$$
\begin{aligned}
\text { Biomass }(\mathrm{P})_{\mathrm{t}+1}= & \text { biomass }(\mathrm{P})_{\mathrm{t}}(1+\text { photosynthetic growth } \pm \text { advection }- \text { excretion } \\
& - \text { respiration }- \text { predation }- \text { mortality })
\end{aligned}
$$

3. DETAITUS:
(a) As an external model element
(b) Detritus $_{t+1}=$ detritus $_{t}+\sum_{i}$ \{excretion $_{i}+$ mortality $_{i}+$ settling $j+$ net water column import + net sediment column import - decomposition - predation

\section{POLLUTANT CONCENTRATION:}

$$
\begin{aligned}
& \text { Total pollutant } j \text { in taxon } i=B 1 O_{i, t}\left[c_{p_{t}}+\left(C_{p_{\text {water }}} u_{i_{w}}+C_{p_{\text {sed }}} u_{i_{s}}+C_{p_{\text {food }}} u_{i_{i}}\right)-\right. \\
& \text { excretion } \left.]-C_{p_{i, t}} \text { (bio loss } i\right)-a\left[C_{p_{i, t}} \text { (out recruitment) }\right] \\
& +\mathrm{C}_{\mathrm{p}_{\mathrm{j}, \mathrm{t}}} \text { (bi, gain) }
\end{aligned}
$$

Pollutant concentration $=\left(\right.$ total pollutant $j$ in taxon $\left.{ }_{j}\right) /\left(\right.$ biomass $\left._{j}\right)$

Ffg. 10. Equation sumary for the dynamic ecological model.

II Indicates all nodes from which nontidal flow flows towazd node $l$.

n Indicates ell nodes to which nontidal flow flows from node $\chi$.

m may also be used to Indicate all nodes connected to $\ell$ when flow direction is imaterial.

Taxon Identifiers $j$ and $k$ will also be used in association with the recrultment process. The taxon from which taxon 1 recruits is $j$, and $k$ is the taxon that recrults from taxon 1 .
As examples of this system, $\mathrm{BIO}_{1, t, l}$ is defined as the blomass of taxon 1 at time step $t$ at node $l$, and $B I O_{j, t+1, m}$ is defined as the blomass of predator $j$ at tire step $t+1$ at node $m$.

Subscripts may also be used to Indicate the direction of an action. Thus

$0_{m+1}$

is defined as the mass flow rate from node to to node $\ell$, and 


$$
w_{j \rightarrow k}
$$

1s detined as the preference by predator $j$ for taxon $k$ as a food source.

Not all three subscripts need be included on each parameter. The identification of individual subscript as to taxon, temporal, or spatial definition should be self-evident in each application.

\section{BIOMASS EQUATION}

The terms included in the biomass equation are

$$
\begin{aligned}
\text { biomass }_{1, t+1}= & \text { blomass }_{1, t} \pm \text { recruitment } \\
& \pm \text { advection/migration } \\
& + \text { feeding - excretion } \\
& - \text { resplration - predation } \\
& - \text { mortality. }
\end{aligned}
$$

More speciflcally, all cerms except recrultment and migration are based on specif $1 c$, or unit mass, rates. Thus

$$
\begin{aligned}
\mathrm{BIO}_{1, t+1}= & \pm \text { recruitment } \pm \text { âdvection } \\
& \text { migratior }+\mathrm{BIO}_{1, t} \\
& (1+\text { feeding - excretion } \\
& - \text { fespiration - predacion } \\
& - \text { fortalit } y),
\end{aligned}
$$

where feeding Indicates the unit mass feeding rate.

This biomass equarion is designed to be sufficlently general to allow application to all taxa except phytoplankton. Each term within this equation is discussed separateiy below.

\section{Recruftment}

Recruitment cerms are baged on histor1cal year-class estimates, available field data, and laboratory data on reproduction.
Eased on such data, a basic recruitment equation is

recruitment ${ }_{1}=\left(\operatorname{Rr}_{1}\right)\left(B I 0_{j, t=t_{0}}\right)$,

where $\mathrm{Rr}_{1}$ is the daily recrultment rate for taxon 1 neasured as the recrulted mass per unit of "parent" taxon blomass per day. This may be a constant dally rate or may follow a Gaussian or some other distribution, depending on the taxon in question. The other term in Eq. (15), $\mathrm{BIO}_{3, t=\mathrm{t}_{0}}, 1 \mathrm{~s}$ the blomass of taxon $f$ from which taxon 1 recruits at time $t_{0}$, defined as the time step corresponding with the start of recruitment or spatining season, whichever is applicable to the recruttment process in question.

The use of parent blomass on tine Initial time step of recrultment may appear somewhat simplistic. However, the resultant recrultment blomass errors should be small and, more Importanc, avallable data relates original standing stock to biomass of resulting larval of yearmclass entrants. Thus the form presented here allows max1mum utilizetion of existing data.

Three external factors can modify this relationship: temperature, pollutant concencration, and "parent" taxon biomase.

Temperature - Long-term (seasona1) cemperature regime changes fsuch as at the outfall of a power plant) wil: affe:t recruttment (Clark and Browell, 1973). The first effect will be to reduce the time interval between spawiag and recrultment; the second effect will. be to reduce intelal larval survival as a result of early recrultment. If temperature-dependent time 
controls can be used for these reproductive activities, then the temperacure effect of initially reduced survival could be disregarded. This second effect 1s much smaller than elther the first temperature effect $\sim r$ the effect of increased predation caused by temperature-induced early arrival of a spectfic larval taxon. This increased predation will be automatically picked up by predaclon cerms in the blomass equacion if temperature control of the time of recruftment can be included.

\section{Pollutant Effects - Pollutant effects will} be constdered primarily on the spawning and larval recrultment term. Thus effects on reduction of spawning-adult fecundty, effects of Increased pollutant concentration $1 \pi$ eggs, and resultant decreased hatch rate will all be incurporated into a single effect term applied to the larval recruitment term. Secondarily, pollutant effects on larval molcing success will be considered. Tine exact form of this relationship has not yet been determined and w111 be based on an extensive literature searcin.

Population Effects - When data for local taxon-carrying capactty are known, a population-dependent term based on that figure can be inserted. The effect of this cerm has been well established (Park et al., 1974; Shugart et al., 1974). Large parent populations result in reduced reproduction rates. W1thout analyzing the hasis for this reduction, we can Incorporate it into the larval recruitment process--the only recruitment affected by chis population phenomenon. The resulting form of this equation normally presented is (Park et al., 1974)

reduced recruitment $t_{1}=b_{1}\left(\frac{k_{c, j}-B_{j, t=t_{0}}}{k_{c, j}}\right)$, where $b_{i}$ is a constant, dependent on the characteristics of the taxon involved and $k_{c, j}$ is the loral carrying capacity of the environtnent for taxon i from which taxon 1 recruits.

However, the functional shape of this expression is applicable only for $B I 0_{j}>$ $B I O_{j}^{*}$ (where BIO ${ }_{j}^{*}$ is the minimum population level for these population-density effects to be felt). The critical population is then that portion of the total taxon population in excess of BIOt. Thus a more representative equational form is

recruitment reduction factor into taxon 1

- 1 for BIO $_{j, t=\varepsilon_{0}}<\mathrm{BTO}_{j}^{*}$,

$=b_{1}\left(\frac{k_{c, j}-B_{j, t}=t_{0}}{k_{c, j}}\right)$

for $\mathrm{BIO}_{\mathrm{j}, \mathrm{t}=\mathrm{t}_{0}}>\mathrm{BIO}_{\mathrm{j}}^{*}$.

In this equational form it is critical that the parameters $K_{c, j}$ and $B I O_{j}^{*}$ be known. However, for the marine/estuarine environment these terms have not been calculaced beyond primary process levels. Furthermore, the cerms are nelther spatially nor temporally constant as a result of the variability of an estuarine environment.

This study will therefore use the equational form

recrultment reduction inco taxon 1

$=A_{i} \exp \left(-\frac{B I O_{f}^{2}}{B I O_{0}^{2}}\right)$,

where $\mathrm{BIO}_{j_{0}}$ represents a constant popula- 
tion level (the half-saturation constant) that with the constant $A$ will be deternij, ed by parametrization of existing data.

This function more closely mirrors the natural functional form over the full range of $\mathrm{BIO}_{f}$. Since these population effects are felt on larval recruitment only, a coefficient $\left(b_{i}\right)$ must be inserted to reduce this term to unity in the recruitment expression for nonlarval stages.

Since the recruitment process involves mass transfer from one taxon to another, each taxon recruited from must be assessed a mass loss during the appropriate periods (e.g., spawning seasons for the adult-tolarval recruitment process?. This mass loss must be equal to or larger than the mass recruited into the recruiting taxon to iccount for mass released from one taxon (such as portions of eggs not wholly consumed, eggs not hatched, eggs consumed by predators, energy losses during hatching and incubation) and not accepted as new biomass into the appropriate receiving tazon. In the case of most spawning adults, and especially for some benthics, this additional loss is very large (F1llice, 1958; Altman and Dittmer, 1962; Park et al., 1974). With most larvals molting into adults, the additional loss is small or negligible. This loss can be estimated by calculating the mass recruited into the taxon recruiting from the taxon in question multiplied by a taxon speciflc additional loss factor. Equationally, this loss per time perlod, or per day, is

$$
\operatorname{loss}_{1}=\frac{\mathrm{Rr}_{1 \rightarrow k} \mathrm{~S}_{k} \mathrm{~L}_{1}}{\mathrm{~S}_{1}} \text {, }
$$

where $\operatorname{Rr}_{i \rightarrow k}=$ dally recrultment rate by $k$ from $i$ during $k^{\prime} s$ recruitment season, $S_{k}$ is the length (in days) of the recruitment season of taxon $k, S_{i}$ is the length of spawning season of taxon 1 , and $L_{i}$ is a taxon-specific additional spawning loss coefficient, approximately unity for adult recruitment stages and greater than unity for larval recruitment.

The fi.. rorruitmont term of the blomass equation is as follows for caxon 1:

$$
\begin{aligned}
\text { Recruitment }= & z_{1}\left(f_{\Sigma p}\right)\left(R r_{j+1}\right)\left(B I 0_{j, t=t_{0}}\right) \\
& \times b_{1} A_{1} \exp \left(-\frac{B I 0_{j}^{2}}{B I 0_{j}^{2}}\right) \\
& -z_{2}\left(\frac{L_{1} R r_{i+k} s_{k}}{s_{i}}\right)
\end{aligned}
$$

where $z_{1}$ and $z_{2}$ are temperature-dependent timing functions and are equal to unity if recrultment into or out of taxon $i$, respectively, is ongoing and equal to zero if not. Mean dally temperature levels will be used to modify the number of days between a shift of $z_{1}$ or $z_{2}$ from 0 to 1 or from 1 to 0 . The coefficlent $b_{1}$ in Eq. (19) is defined as

$$
b_{i}=A_{1}^{-1} \exp \left(+\frac{B I O_{j}^{2}}{B I O_{j_{0}}^{2}}\right)
$$

for adult-stage recruitment and

$$
b_{1}=1
$$

for larval-stage recrultment,

Feeding

Under the assumption and $11 \mathrm{~m} 1 \mathrm{tat}$ ions defined for the $I / 0$ model, the mass trans- 


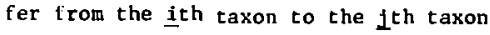
(feeding by $j$ on 1 ) is represented by $x_{1 j}$, with $x_{i}$ and $x_{f}$ representing the standing stock or the bjomass of each of these taxa, respectively. It was further shown that, if $X_{i}$ repiesents a nonlimiting food supply for $f$ and if the demand for $x_{1}$ by $x_{j}$ was unencumbered, or nonelastic (1.e., demand by any one organism within $x_{j}$ does not affect the ability of other organiams to fulf 111 their demand for $x_{1}$ ), then the transfer $x_{i f}$ was linearly proportional to $x_{j}$ and a meaningful term, $a_{1 j}$, would be established as

$$
a_{1 j}=\frac{x_{11}}{x_{j}} \geqslant \frac{\text { Biomass }_{1+1}}{\text { Blomass }_{j}}
$$

with the total dernand for food, or total feeding, by $x_{j}=\Sigma_{1} a_{i, j}$ BIO $_{j}$. This amount of feeding represents an optimum, or maxImun, amount of feeding that $x_{j}$ can perform. Furthermore, $\Sigma_{1} a_{1, j}$ can be called the maximum feeding rate $\left(F R_{j}\right)$ per unit biomass of $j$, so that

$$
\text { feeding }=\mathrm{FR}_{\mathfrak{f}} \mathrm{BIO}_{\mathrm{j}} \text {. }
$$

To generalize away from this ideal feeding situation, factors must be included in the equation to account for suboptmal environmental feeding cordittons. Thus

$$
\begin{aligned}
\text { feeding }_{j}= & \left(F R_{j}\right)\left(B I O_{j}\right)\left(f_{\Sigma p}\right)\left(f_{\sum e n v}\right) \\
& \times\left(f_{B I O_{j}}\right)\left(F_{B I O_{1}}\right)
\end{aligned}
$$

where $f_{\Sigma_{p}}$ is the effect on feeding of pollutant concentrat ton present in taxon $f$, $f_{\text {Eenv }}$ is the effect of a suboptimal envi- ronment, $\mathrm{F}_{\mathrm{BIO}_{1}}$ is the ef fect of a limited food supply, $\hat{\mathrm{BIO}}_{\mathrm{f}}$ is the effact of encumbered feeding.

Analyzing these in reverse order, it has been well established that large feedIng populations reduce unit mass feeding regardless of food-supply avallability (Park et al., 1974; De Angel1s, 1975; Fox, 1975). This may be a result of 1ncreased canntbalism or of physical interference. However, the phenomenon definitely exists. The general functional shape of this effect 1s shown in Fig. 11. The equation form of this graph is

Feeding $=x_{1 j}=A_{j \rightarrow 1} \exp \left(-\frac{\mathrm{BIO}_{f}^{2}}{\mathrm{BIO}_{\mathrm{j}_{0}}^{2}}\right)$

Differing mathematical forms of the phenumenon have been based on the "carry capacity" of the local environment for a given taxon. However, this parameter has not been Identified for the widely varying estuarine environment. Half-saturation constants--or that population size for which untt mass feeding is reduced to onehalf of the maximum feeding rate--have

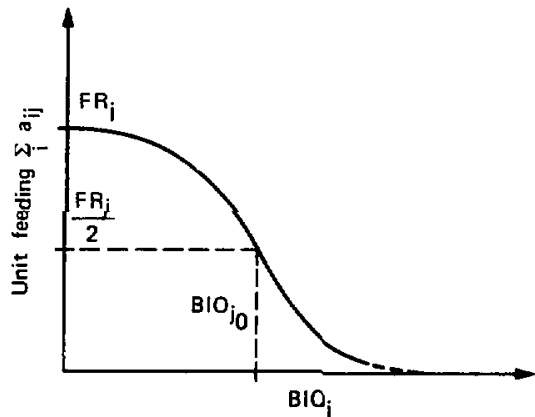

F1g. 11. Dependency of unit feeding rate on taxon biomasa. 
been established for a number of species and are more easily obtainable by direct experimentation (Chen and Orlob, 1975).

The parameters $A_{j \rightarrow 1}$ and $\mathrm{BIO}_{j, 0}$ must be determined experimentally for each feeding taxon and feeding link.

The effect of a limited food supply Is to limit total feeding for small-foodsupply blomasses. Complicating this relaIlonship is the fact that the estuarine food web is very loosely structured, each predator having a variety of potential food sources. The general effect of foodsupply size on total feeding is shown in Fig. 12 .

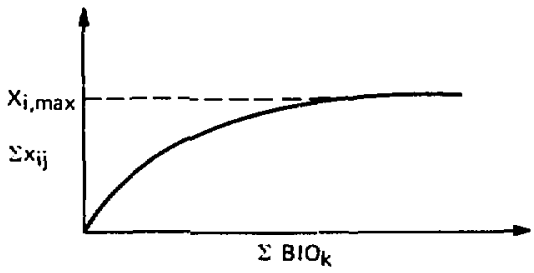

F18. 12. The relationship between foodsupply blomass and predator feeding.

This relationship can be expressed as (Isaacs, 1972)

feeding ${ }_{j}=\sum_{k}\left(\frac{\text { BIO }_{j \rightarrow k^{W}}{ }_{j \rightarrow k}}{C+\sum_{k} B I O_{j \rightarrow k}{ }_{j \rightarrow k}}\right)$,

where $B 1 O_{j \rightarrow k}$ is the blomass of the $k t h$ food source or prey for predator $1, C$ is a constant (may be the half-saturation constant for $x_{j}$ feeding on $x_{1}$, and $w_{j \rightarrow k}$ is a parameter that represents the predator ( $j$ ) prefcrence for, and ability to catch, food source $k$. Numerically it is the relative amount of $k$ that would be consumed by a untt mass of $j$ over some specifled time period
If $j$ were simultancously presented with an equal biomass of each potential food source (0'Ne111, 1969).

If the feeding term is now divided by bio, to present feeding per unit biomass of $j$, we have, for feeding by $j$ th predator on all prey:

$$
\begin{aligned}
& \text { unit feeding }{ }_{j} \equiv \text { feeding, } \\
& =\left(F R_{j}\right)\left[A_{j} \exp \left(-\frac{B l 0_{j}^{2}}{B I 0_{j_{0}}^{2}}\right)\right] \\
& \times\left(\sum_{k} \frac{\text { BIO }_{j \rightarrow k} w_{j-k}}{c+\sum_{k} \text { BIO }_{j \rightarrow k} w_{j+k}}\right) \\
& i\left(f_{\Sigma_{p}}\right)\left(f_{\text {Ienv }}\right) \cdot
\end{aligned}
$$

$$
\begin{aligned}
& \text { The } \mathrm{f}_{\text {Ienv }} \text { term can be expanded to } \\
& \mathrm{f}_{\text {Ienv }}=\mathrm{f} \text { (temperature, salinity, dissolved } \\
& \text { oxygen, turbidity, current, ph). }
\end{aligned}
$$

Two general functional relationsh 1 ps may be used to characterize the effect on feeding of each of these environmental parameters. These are 11lustrated in Fig. 13.

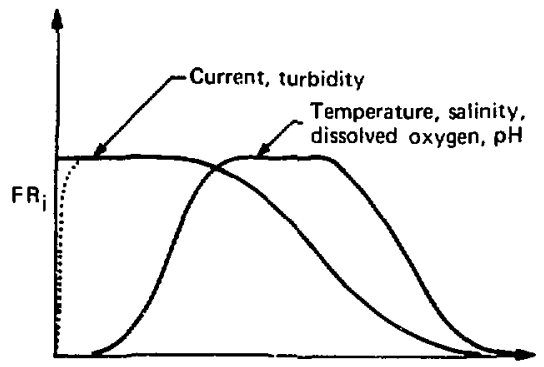

Environmental parameter value

F18. 13. Generalized environmental parameter modiftcation of unit feedIng. 
The general equational form of each of these relationships is easily established. However, no additfonal work is anticlpated on defining which of the above mentioned environmental parameters will be included, or on parametrization of the various constants associated with the mathematical form of these relationships, until specific areas and seasons of concern have been defined (see $\mathrm{F} 1 \mathrm{~g}$. 4). At that time an appropriate effort can be made to define the physical environmental regions and abloticblotic relationships associated with 1 t.

Finally, $f_{I_{p}}$, or $f\left(P_{1}, P_{2}, \ldots, P_{n}\right)$ has an effect on feeding for each $f\left(P_{1}\right)$ similar to that defined for turbidity and current. Again, no additional effort w1ll be expended on this term until "pollutants of concern" have been defined by the hydrodynamic, dispersion, and. sediment-transport models and by an extensive literature search on pollutant uptake and effects.

With feeding thus defined, the addition of blomass into the 1 th taxon can be defined as

unit increased blomass $1=\mu_{1}$ (feed $1 \mathrm{ng}_{1}$ ),

where $\mu_{1}$ is the assimilation rate of mass consumed to resultant blomass increase. The value of $\mu_{i}$ vartes between about 7 and about $15 \%$ for most marine and estuarine species.

Thus the feeding term for the ith taxon in the biomass equation can be summarized as follows:

unit Increased biomass 1

$$
=\mu_{1}\left\{\left(\mathrm{FR}_{1}\right)\left[\mathrm{A}_{1} \exp \left(-\frac{B I 0_{i}^{2}}{B I \mathrm{I}_{0}^{2}}\right)\right]\right.
$$

$$
\left.\times \sum_{k} \frac{\mathrm{BIO}_{1+k^{\mathrm{W}}}{ }_{i+k}}{C+\sum_{k} \mathrm{BO}_{i+k} \mathrm{w}_{1+k}}\left(\mathrm{f}_{\Sigma \mathrm{p}}\right)\left(\mathrm{f}_{\Sigma \mathrm{env}}\right)\right\} .
$$

Advection and Migration

Two separate terms are used to define change of taxon blomass at any given node due to biomass flow across rodal boundarles: advection and migration. Advection is Involuntary movement as a result of advective current flow. Migration is voluntary self-induced movement from one node to another. Advection requires that organigms float but cannot swim; migration requires a swimming or crawling abflity. These two types of biomass redistribution would seem to be mutually exclusive. There are, however, a large group of organisms (Including many larval stages, zooplankton, and some benthics) that can swim but not we11 enough to overcome many advective current flows. Thus their movement is a function of both cholce and current flow.

Advection - The advection term is a simple nodal mass and flow balance:

$$
\begin{aligned}
\Delta \mathrm{BIO}_{1, \mathrm{t}+1, \ell}= & {\left[\sum_{\mathrm{m}}\left(p_{1, \mathrm{t}, \mathrm{m}} \mathrm{Q}_{\mathrm{m}+l}\right)\left(\mathrm{f}_{i, \mathrm{~m} \rightarrow l}\right)\right.} \\
& \left.-\sum_{\mathrm{m}}\left(p_{1, \mathrm{t}, l} \mathrm{Q}_{\ell+\mathrm{n}}\right)\left(\mathrm{f}_{1, l \rightarrow \mathrm{m}}\right)\right],
\end{aligned}
$$

The quantity $p_{i}$ is the denstey of taxon 1 , and $Q_{m \rightarrow l}$ is the net nonfidal mass flow rate from node $m$ to node $\ell$ at time $t$. These "link" flow rates are a normal parameter already generated by the hydrodynamic program. The 1ast term in Eq. (26), $f_{i, l \rightarrow n}$, is a dependency factor of 
taxon $i$ on current novement along link \& to $n$.

This factor is current velocity dependent for some taxa (1.e., those that are partially dependent on current movements for migration). It is zero for sessile raxa, unity for planktonic taxa with no swimming ability, and ( $\left.1>f_{i} \geq 0\right)$ for all other taxa.

Gamefish, commercial flsh, and commerclal crustaceans will probably be assigned $E_{1}=0$, even though the current does have some effect on their movement (Perkins, $1974)$.

Migration - The migration term will be based on the form of human ingration used in regional economics (Isard, 1960):

$$
\begin{aligned}
\text { migration }_{i, m+l}= & \frac{\text { population }_{1, m}}{\text { distance }_{m \rightarrow l}} \\
& \left(\text { desirabllity }_{\ell}\right)
\end{aligned}
$$

so that net migration between two nodes, m and $l, 1 s$

$$
\begin{aligned}
& \text { net } \text { mgration }_{i}=\frac{\left(B I 0_{1, m}\right)\left(\text { desirab111ty }_{l}\right)}{\text { distance }} \\
& -\frac{\text { BIO } \left._{i, \ell}\right)\left(\text { desirability }_{m}\right)}{\text { distance }}
\end{aligned}
$$

Applying this equation to the nodal/link system being used in this model, in which all link lengths are known, the biomass of taxon 1 at time $t$ is known for each node, the net migration into node $\ell$ is defined as migration $_{i, t+1, \ell}$, and where $m$ denotes all nodes 1 inked to $\ell$, we obtain

$$
\begin{aligned}
& \text { mígration } i, t+1, l \\
& =\sum_{m}\left[\frac{\left(B I O_{1, t, m}\right)\left(2_{1, \ell}\right)-\left(B I 0_{i, t, \ell}\right)\left(2_{1, m}\right)}{\text { distance }{ }_{m \rightarrow l}}\right] \\
& \left(1-f_{i, m \ell \ell}\right) \text {, }
\end{aligned}
$$

where $z_{1, l}$ is the desirability to taxon 1 of migrating to node $\ell$ and $\left(1-f_{1, n \rightarrow l}\right)$ is that part of the movement by taxon 1 that is not controlled by advective flow along $11 n k m \rightarrow$, or that part of 1 ts movement that is controlled by Individual cholce. It has been established, especially for pelagics, that even minor migrational movements are not totally random in nature but have some net directionality (Harden Jones, 1968). Thus the concept of "cholce" does have definite neaning here even when applied to feeding movements.

The tera $Z_{1, \ell}$ requires additional explanation. It is anticipated that this term will be a function of environmental parameters, pollutant concentration, and food supply. If one or more of these factors are more desirable (closer to optimum for the taxon) at node $\&$ than at node $\mathrm{m}$, a migration will be Induced for taxon 1 from m to $l$ that is proportional to the 1 creased desirab1l1ty of $l$. The term $Z_{i}$ is expanded as follors:

$$
\begin{aligned}
z_{1}= & z \text { (temperature, salinity, turbidity, } \\
& \text { food supply, } \Sigma p)
\end{aligned}
$$

Each of tinese flve parameters, varying between 0 and 1 , defines the relative desirability of a given node for that one environmental parameter. Their product is $z_{1, l}$. The functional form of the relationship between node desirability and each of 
these parameters is the same as that between feeding and the parameters discussed In the preceding section on feeding. Their graphical form and functional range are shown in Fig. 14.

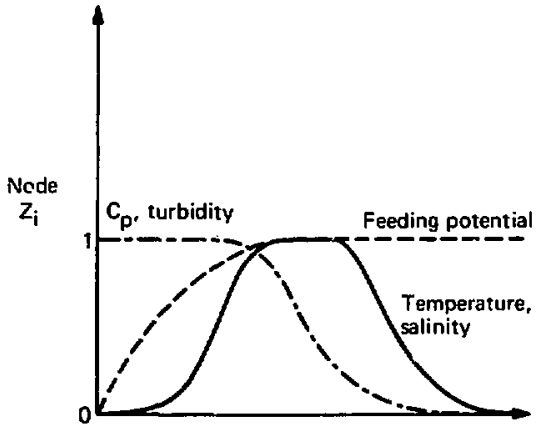

Environmental factor value

F1g. 14. Generalized relationshtp between $z_{i}$ and varlous environmental factors. $\left(C_{p}\right.$ denotes pollutant concentration for a given pollutant $p_{\text {, ) }}$

Using the equational forms of these relationships listed in the section on feeding, we obtaln

$$
\begin{aligned}
& z_{i, \ell}=\left(\frac{\sum_{k} \text { BIO }_{i \rightarrow k} w_{i \rightarrow k}}{C+\sum_{k} \text { BIO }_{i \rightarrow k} w_{i \rightarrow k}}\right)^{b_{f}} \\
& \times\left[\prod_{1} A_{1} \exp \left(-\frac{c_{p_{1}}^{2}}{c_{p_{1,0}^{2}}^{2}}\right)^{b}\right. \\
& \times\left\{\Pi_{1} A_{1} \exp \left[-\frac{\left(E_{o p t}-E_{\text {onv }}\right)^{2}}{\left(E_{\text {n }} v_{o p t}-E_{n v_{1,0}}\right)^{2}}\right]\right\}^{b} \text { env }
\end{aligned}
$$

where $b_{f}, b_{p}$, and $b_{\text {env }}$ are the weighting factors for the relative importance of food supply, pollutant concentration, and environmental quality, respectively. A minor error is potentially introduced here by assuming that temperature and salinity effects are symetrical about the parameter optinum condition. Should this error prove excessive, the equational form can be skewed.

The distance term, also needs further definition. In order to maintain units conceptually compatible with the rest of the biomass equation, this "distance" will be measured in tine untts. Thus $d$ will be measured in tinits of days, and

$\mathrm{d}_{\mathrm{m} \rightarrow \ell}=\frac{\text { length of link m to } \ell \text { (feet) }}{\mathbf{a}_{\mathrm{m} \rightarrow l}}$,

where $\bar{u}_{n \rightarrow \ell}$ is the nontidal advective current over the 1 ink $\pi+h$ measured in feet per day. The advection and migration term can now be summarized as follows:

$$
\begin{aligned}
& \text { net change in blomass } 1, t+1,2 \\
& =\left\{\left[\sum_{m}\left(\rho_{1, m} Q_{m \rightarrow l}\right)\left(f_{1, m \rightarrow l}\right),\right.\right. \\
& \left.-\sum_{n}\left(\rho_{1, \ell} Q_{\ell \rightarrow \pi}\right)\left(f_{1, \ell+n}\right)\right]+\left(1-f_{1, \pi \rightarrow \ell}\right) \\
& \times\left[\sum_{m} \frac{B I 0_{1, m} m_{1,2}-B 10_{1, l}{ }_{1, m}}{d_{m \rightarrow l}}\right],
\end{aligned}
$$

where $z_{1,2}$ is given by $\mathrm{Eq}$. (31).

\section{Excretion}

For the purposes of this study excretion is defined as all mass that is eaten and does not become new taxon blomass.

Thus excretion can be writcen as

excretion $_{1}=\left(1-\mu_{1}\right)($ feeding $)$, 
where ${ }_{1}$ and fecding are as defined in the section on fectinis.

This simplified viets of excretion and "I Igncres both additio al losses in the form of energy required for digestion and utilization and the form of the excreted tatter (Park, 1976). In a more rigorous treatment, if would normally tupresent the percentage of food ingested (and sould be litrer than the is used here). Respiration rates would then be increased as at function of iagest in to reflect digestive and we 1 lization prucesses, and excretion yould be rculced by this same amount. This mote riporous approach is not being taken here for two reasons:

1. Ease of data acquideton. The $H_{1}$ used here is far easter to determine experimentaliy and is already avallable for many spretes.

2. We error Is generated in the bjomass equation is a direct result of this simplification. If the energy losses being ignored here are represented collectively as $H_{e}$, conversion to the nore detalled system would be as follows:

$$
:_{1, \text { detalled }}=H_{1}+M_{e}
$$

and

$$
\text { respiration }{ }_{i \text {, detailed }}=R_{1}+M_{e} \text {, }
$$

where $v_{i}$ is as included in the feeding term. Since the biomass equation includes the terms (+ feeding) and (- respiration), the $M_{e}$ term is canceled out. An error is generated here as an overestimation of excretory mass. Should this generate significant additional errors (as overestimation of detricus food supply), a constant fac- tor can be applied to excre:ion to reflect chese energy losses, and

$\operatorname{axcrecion}_{1}+c_{1}\left(1-w_{1}\right)\left(\right.$ feed $\left.\ln \mathrm{s}_{1}\right)$

\section{Resplration}

As Indicated in the preceding section, the definition of respiration used here is a somewhat simplifled one. Respiration is taken to depend on tenperature only, so chat

$$
R_{1}=\hat{\tau}_{1, I_{0}} \theta_{1}^{\left(T-T_{0}\right)}
$$

where $\hat{r}_{1}, T_{0}$ is the specific resplration rate at cemperature $T_{0}$ (normally taken between 18 and $20^{\circ} \mathrm{C}$ ), $\theta$ is th: taxondependent temperature coeffictent ranging from 1.02 to 1.06 (Chen and 0rlob, 1975), and $T$ is the awblent water-calumn temperature.

\section{Predation}

While feeding is a measure of a given prediator taxon's consumption of a number of separate prey caxa, natural predacton is a measure of the consumption of a given taxon by a number of separate predator taxa. More specifically, it is the sum of the portion of each predator taxon's total feeding that consists of a fiven pres' species, or

predation on $1=\sum$ (total predation by each predator taxon $j$ ) (percent of each predator's consumption representing taxon 1).

Under the discussion of feeding, an expression was developed to describe total feeding by any taxon. Also in that section 
there was developed an expression for the percentage of a predator taxon's total diet couprised by a given taxon. From these expressions we obtain

$$
\begin{aligned}
\text { predation on } 1= & \sum_{j}\left(\frac{\text { BIO }_{i} w_{j \rightarrow i}}{\sum_{k} \text { BIO }_{j \rightarrow k} w_{j \rightarrow k}}\right) \\
& \times\left(F R_{j}\right)\left[A_{j} \exp \left(-\frac{B I 0_{j}^{2}}{B I 0_{j}^{2}}\right)\right] \\
& \times\left(\sum_{k} \frac{B I 0_{j+k} w_{j \rightarrow k}}{\sum \sum_{k}{ }_{j \rightarrow k} w_{j+k}}\right) \\
& \times\left(f_{\sum p \rightarrow j}\right)\left(f_{\sum \text { env } \rightarrow j}\right)
\end{aligned}
$$

Total predation equals natural predation plus human harvest. Human harvest can be Included in any of several ways as follows:

1. As an externally defined constant baged on recorded fish landings.

$\dot{2}$. is an exogenous varlable defined for any taxon in any given manner to allow management-decision control of fisheries.

3. As a percent of total available taxon blomass based on historlcal records.

Since this study does not now Include any fisheries-management objectives, option 2 will not be considered. Option 3 requires additional data on actual game and commercial specles blomass. Although these data are collected for a few extremely Important species (e.g., striped bass) at the state level in California and stored for computer analysis, it is not generally known on a year-by-year basis for all harvested species. Thus option 1 will be used InItlally, but the abillty w1l be retained to shift to a size-dependent expression involving mass and year class should the nec- essary data become avatlable. A parameter of legality and marketability $\left(f_{1}\right)$ will be used to modify human harvest. This term will range from 0 to 1 based on pollutant and toxin concentrations within each harvested taxon and will reflect both reduction in marketability for such reasons as tainting or higher 011 and grease content, ant legal closures of certa1i. fisheries (e.g., clam or oyster) when pollutantconcentration health 1 Imits are exceeded. Normally a legal concentration of pollutant $1 \mathrm{~s}$ exceeded before the species is naturally unmarketable.

In assessing the parameters associated with the mathematical form of this relaclonship (shown In $\mathrm{FI}_{g} .15$ ), several economic simplifications have been made.

Specifically, demand elasticity and product substitution rates w11l be Ignored. Paramatrization of this function w1ll be based largely on gamefish talnting tests conducted by the Californla State Department of F1sh and Gaze (Kopperdah1, 1971; Hazel et a1., 1971).

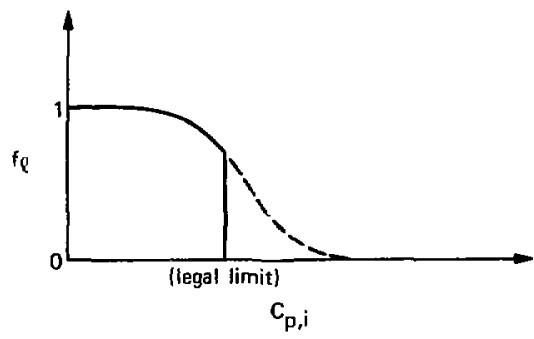

Fig. 15. Pollutant modification of human harvest.

Thus human harvest can be expressed as

harvest $_{1}=\left(f_{Q}\right)\left(P_{h}\right)$, 
where $P_{h}$ is the human-harvest predation and may become a biomass-dependent term. Total predation is thus equal to $P_{1}+f_{l, 1} P_{h, 1}$, where $P_{1}$ is given by Eq. (37).

\section{Mortal1ty}

Mortality is the nonpredation loss for any taxon. It is considered here as a dependent function of the natural mortality rate, pollutant and toxin concentration, temperature, and Feeding rate. Temperature is Included here only for analysis of thermal-d1scharge effects. Temperatures within the natural estuarine systen do not tend to approach lethal limits (Pearson et al., 1965, 1967; Kalser Englneers, 1969). Population size is not included as a determinant of nortality since it is felt that the effects of overcrowding are found primarily in association with reduced potential unit feeding. Thus resultant increased mortality can be related more successfully to a critical minimum feeding rate than to the population size, which is only one determinants of feeding rate. Salinity has not been Included, even though many spectes, espectally microbenthos and plankton, have rather sharp, well-deflned limits on salinity tolerance. This exclusion is based on the taxon-inclusion criterla listed on page 6, espectally on criterion 2. It is anticipated that planktonic species will be lumped Into a single listing over wide estuartine segments or, possibly, over the entire estuary. The same is true for microbenthic species. Thus a taxon consisting of spatially integrated salinity-sensitive species will have a similar representation at any salinity level since an integration across the hor1zontal spatial dimension of an estuary is also an Integration over the full range of potential estuarine salinity levels. The probable result of this is that natural mortality levels $\left(x_{1}\right)$ for these taxa w111 be somewhat higher than Indicated by the mortalicy levels of each Individuel specles. This rise will account for salinicyInduced kflls resulting from advective migration of a spectes out of a desired salinity range.

The functional relationsalp between mortality and the three Independent variables within the mortality term are shown in F1g. 16. Relative normal bay limits (Pearson et al., 1967) for temperature are indicated relative to the mortality rate

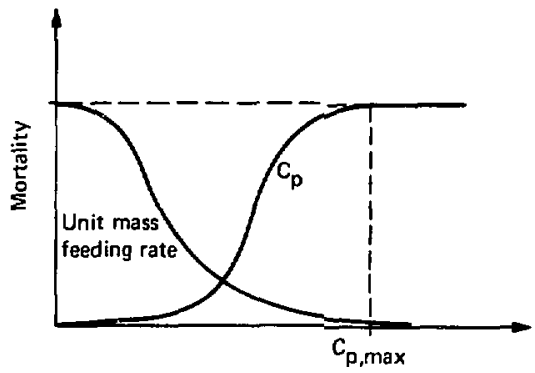

Factor value/concentration

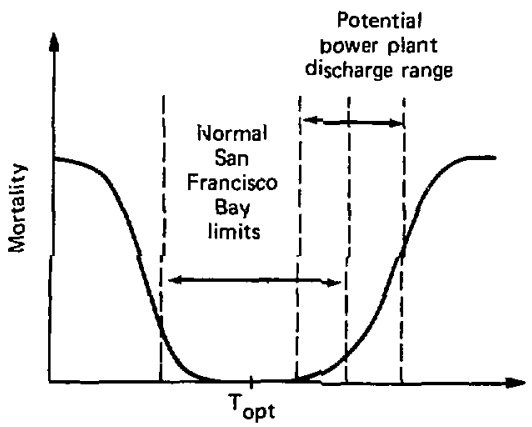

Temperature

$\mathrm{FIg}$. 16. Generalized influence of temperature, feeding rate, and pollutant concentration on taxon unit mortality. 
curve to show the absence of 1ts Influence on wortality under normal conditions.

Thernal-d1scharge Influence is depicted to Identify the portion of the tenperaturewor'al1ty curve of concern. Though each taxon has different temperature linits and temperature senaltivities, the relationshipe depleced are typical of any escuarine spec1es (Grcen, 1968; Mclusky, 1971; Perk1ne, 1974),

It is currently ancicipated that the effects of each of these influences w111 be IInearly additive. This does not wean that potential synetgistic effects in the presence of wore than one pollutant are d1scounted-only that the total pollutantInduced $k 111$, the temperature-1nduced $k 111$, and starvation k11ls will be addicive. Even this, in fact, may not be true, and low feeding rates may leave an organian more susceptioit to pollutant toxicity. However, at this time the general form of the mortality term is

$$
\begin{aligned}
& \operatorname{mortallty}_{1}=\alpha_{\perp}\left\{1+\prod_{j} A_{p_{j \rightarrow 1}}\right. \\
& \times \exp \left[-\frac{\left(C_{P_{\text {max }}+1}-c_{P_{1}}\right)^{2}}{\left(c_{P_{\text {max }}+1}-c_{P_{1}}\right)^{2}}\right] \\
& +A_{F_{1}} \exp \left(-\frac{F_{1}^{2}}{F_{1_{0}^{2}}^{2}}\right) \text {. } \\
& \left.+\mathrm{A}_{\mathrm{T}_{1}} \exp \left[-\frac{\left(\mathrm{T}_{1, \mathrm{opt}}-\mathrm{T}\right)^{2}}{\left(\mathrm{~T}_{1, \mathrm{opt}}-\mathrm{T}_{1_{0}}\right)^{2}}\right]\right\}
\end{aligned}
$$

where $F$ is the unit mass feeding rate, $C_{P_{0}}$ and $T_{0}$ are the 96-hour $I D_{50}$ levels for taxon 1 , and $C_{P_{\max } \rightarrow 1} 18$ the concentracion of pollutant for the 96-hour $L D_{100}$ for caxon 1.

The entire blomasf, equation is shown in F18. 17.

\section{PRIMARY FRODUCTION}

Within the estuarine environment, primary production is essentially limited to phycoplankton production. sajor exceptlong, such as eel-grass beds, are not algnificantly fresent in San Francisco gay except along the northern fringe marshes (Pearson et al,, 1966; Kalaer Engineers, 1969), which will be kept external to the model and treated as import terms. A basic equation for phytoplankton biomass is simflar to the general blomass equation and can be expressed as follows:

$$
\begin{aligned}
& \operatorname{BIOP}_{1, t+1, \ell}=\operatorname{BIOP}_{1, \tau, \ell}\left(1+\mathfrak{a}_{1} f_{\Sigma p} f_{\Sigma e n v}\right. \\
& -\sum \text { predation }-R_{1} f_{\text {temp }} \\
& + \text { advection }_{1} \text { - excretion } \\
& \text { - mortalicy } \left.f_{\Sigma_{p}} f_{\text {temp }}\right) \text {. }
\end{aligned}
$$

The only term not represented here is a recruttment term. Obviously, primary producers will not recrult either into or out of a Biven taxon. Provision has been made In this equation for more than one phytoplankton taxon, as it is most probable that lumpling of all planktonlc species into a single taxon will not be possible.

In the primary production equation, the principal term is the growth term $\left(\hat{\mu}_{1} f_{\Sigma p} f_{\Sigma e n v}\right)$, where $\hat{\mu}_{1}$ is defined as the specific maximum growth rate for that taxon. 


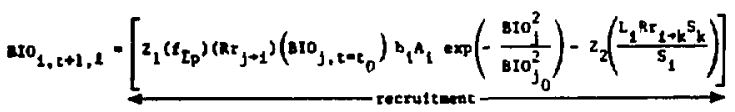

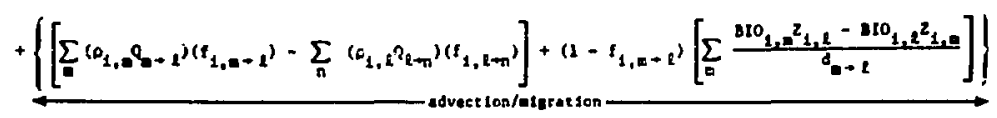

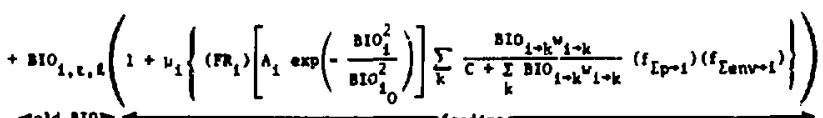

4old tor-

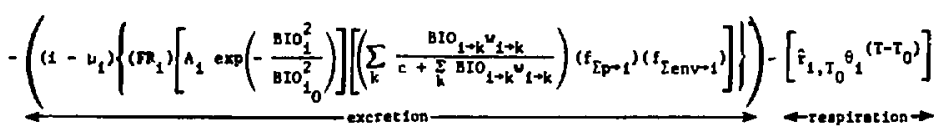

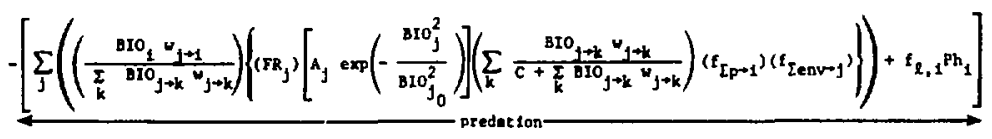

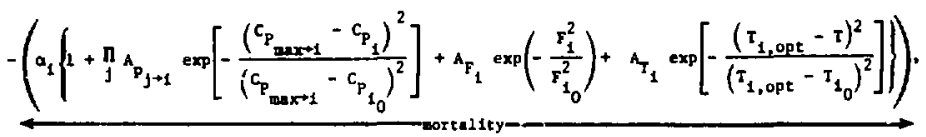

where $z_{1, l}$ 1s defined at

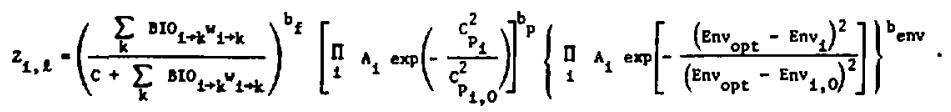

F1g. 17. The complete biomass equation. 
The terms $f_{\text {Ip }}$ and $f_{\text {Ienv }}$ act as suboptimal condition modifiers of that growth rate (Park et ai., 1974). The term $f_{\sum_{p}}$ is ancicipaced to play a minor role in retardIng marine photosynthet1c growth; however. Insufficlent research has been conducted to date to allow 1 ts cotal deletion. The cerm $f_{\text {Ienv }}$ can be expanded to

$$
i_{\text {Ienv }}=\prod_{j}{ }^{f} f_{\text {temp }}
$$

where (based on Chen and 0rlob, 1975)

$$
\hat{\sigma}_{j}=\frac{c_{j}}{k_{0 j+1}+c_{j}} \text {. }
$$

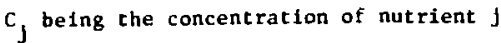
at node $\ell$ and $t$ ime $\tau$ and $K_{0 \rightarrow 1}$ being the half-saturation constant for nutrient $j$ on taxo.1 1 and $f(T)$ as shown in Fig. 18 .

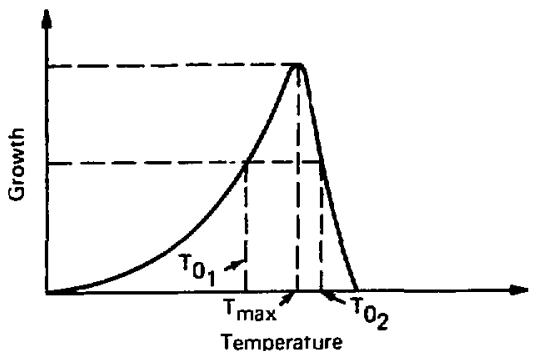

FI8. 18. Relationship between phytoplankton growth and temperature.

As Indicated in Fig. 18, growth increases exponentially to some $T_{\max }$ and then falls off very sharply (Nielsen, 1964; Department of Fish and Game, 1972). The temperature for maximum growth, $T_{\text {max }}$, Is rarely reached or exceeded within the normal estuarine temperature regime.
Therefore the expression $\underbrace{l-T_{0}}$ is oilten used as a simplified temperature-effect form. However, chis study will Incorporate Investigation of theral discharges tinat may locally exceed $T_{\max }$. Therefore the full expression for this functional relationship musc be used. This relationship is, referritis t Fig. 18, as follows:

$$
\begin{aligned}
& \text { For } T \leq T_{1, \operatorname{mix}}, \text { the temperature effect } \\
& \text { for taxon } 1, E_{T, 1} \text {, is }
\end{aligned}
$$$$
E_{T, 1}=\Lambda_{T, 1} \exp \left[-\frac{\left(T_{1, \max }-T\right)^{2}}{\left(T_{1, \max }-T_{1_{0}}\right)^{2}}\right]
$$

and for $T>T_{i, \max }$,

$$
E_{T, 1}=s_{T, i} \exp \left[-\frac{\left(T_{1, \max }-T\right)^{2}}{\left(T_{1, \max }-T_{1_{0}}\right)^{2}}\right] \text {, }
$$

where $\mathrm{T}_{\mathrm{IO}_{1}}$ and $\mathrm{T}_{\mathrm{i}_{2}}$ iepresent the halfsaturation or half-growth constants for taxon 1 .

The use of a half-saturation constant for light should be explained. The amount of light avallable for photosynchesis is actually a function of variable Incident light and exponentially cecaying light strength with depth, curbidity, depth of the photic zone, the quanticy of organic matter in the water column, and so forth (N1elsen, 1964; Hardy, 1965, Vol. 1). However, it must be remembered that oneday time steps will be used in this moral and that the photic zone In San Francisco Bay is of ten less than 4 feet deep. Under 
these conditions the use of water-column and cise-averaged 11 gitt-intonsicy figures Is fustifiab،e, and the half-uaturation constant becomes applicable.

The predation ceism of the primary production equation Is Identical with the predation cerm of the biomass equation [see Eq. (37)].

Resplration can be represented by a specific respiration rate times a cemperature function:

$$
\text { respiration } 1=\hat{E}_{1} f(T)
$$

Respiration, as opposed to feeding, does Increase exponentially over the full cemperature ange (Green, 1968). Thus resplration can be expressed as

$$
\text { respiration }=\hat{r}_{1} \theta_{t}^{T-T_{0}} \text {. }
$$

where $\hat{r}_{1}$ is the specific respiration rate measured at $T_{0}$ and $\theta$ is a caxon-specific constant between 1.02 and 1.06 (Chen and Orlob, 1975).

The advection term is also as shown in the blomass equation. It must be remembered that, as each taxon represents large spatial integrations, salinity variations from node to node need not be considered. Advection is thus represented by

$$
\begin{aligned}
\operatorname{advection}_{1} & =\sum_{m} \rho_{1, m^{Q}} \cdot \ell \\
& -\sum_{n} \rho_{1, \ell} Q_{\ell \rightarrow n} .
\end{aligned}
$$

The $f_{i, m \rightarrow l}$ term need not be included, as phytoplankton have no cholce of movement and, by definition, $f_{1, m \rightarrow l}=1$.

The excretion term is proportional to net phozosynthetic grawth, where the net growth is equal te total growth minus respiration (Park et al., 1974). As a result, the total growth and respiration terms are of ten combined into single net photosynthetic term:

$P_{\text {net, } 1} \cdot \hat{u}_{1} \mathrm{~F}_{\text {i.p }} \mathrm{f}_{\text {Ienv }}-\mathrm{r}_{1} \theta_{1}^{\mathrm{T}-\mathrm{T}_{0}}$.

Excretion, Ex, is then

$$
E x_{1}= \begin{cases}a_{1}{ }^{\prime}{ }_{n e t, 1} & \text { for } P_{\text {net }, 1}>0, \\ 0 & \text { for } P_{\text {net }, 1} \leq 0,\end{cases}
$$

where $a_{1}$ is the fraction of net photosynthate lost per time step.

Under conditions of low photosynthesis and/or high respiration rates (such as at elevated temperatures) excretion goes to zero and all energy losses are through respiration.

The final term, mortality, Includes both actual cell destruction within the euphotic zone and mass settling out of the euphotic zone. Where available, a single coefficlent representing total planktonic mass loss, $d_{i}$, can be used:

specific mortality $=d_{i} f(T) f_{\Sigma p}$.

Where the combined data are not given and data on actual cell death rate and settling rates are available, mortality can be expressed by

$$
\begin{aligned}
\text { specific martality } & =\left(\alpha_{1}+\frac{s_{v}}{z_{\text {photic }}}\right) \\
& \times f(T) E_{\Sigma_{p}},
\end{aligned}
$$


where $a_{1}$ is the actual unit mass celldeath rate, $S_{v}$ is the node average set:ilng velocity, and $z_{\text {photic }}$ is the mean depth of the photic zone at a given node.

The relationship between temperature and wortality is essentially the reverse of that between temperature and feeding and has been previously discussed. The general shape of this relationship is shown in F18. 19. The actual temperature levels for the onset of temperature-induced mortality are, of course, a function of each Individual taxon. However, for the falrly $11 \mathrm{mlted}$ temperature reglwe of San Franclsco Bay [normal surface $11 m i t s$ are about $7^{\circ} \mathrm{C} \leq$ $T_{\text {Bay }} \leq 18^{\circ} \mathrm{C}$ (Kaiser En, ineers, 1967)], 1Imils on Fig. 19 are typlcal of many estuarine species.

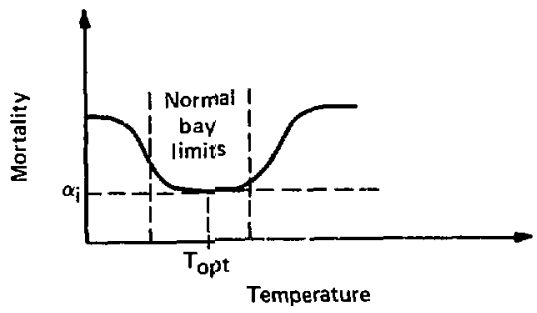

F1g. 19. Relationshlp between water temperature and phytoplankton mortallty.

If symetry about $T_{\text {opt }}$ is assumed, then the temperature influence on the mortality of $\operatorname{tax} 1$ is given by

$M_{T_{1}}=A_{T_{1}} \exp -1 \frac{\left(T_{o p t, 1}-T\right)^{2}}{\left(T_{o p t, i}-T_{o_{1}}\right)^{2}}$

where $A_{T_{1}}$ can easily be determined by makIng $T$ very large and assuming that the total population $k i l l \mathrm{~T}_{0_{1}}$, is the $\mathrm{LD}_{50}$ temperature for the $i$ th taxon and $T_{o p t}$ is the optimum temperature for the taxon.

The wathematical form of the pollutant effects for this equation will also be left unt 11 the specific pollutants of concern have been determined and uncil a more thorough literature search has been made.

The primary production equation is sumarized in Fig. 20.

\section{DETRITUS}

Detritus has no direct impact importance. Thus the goal of this study in dealing with detritus is to externalize and simplify detrital mapping as much as possible. The principal limiting factor in this simplification process is the requirement to track pollutant concentration through detrttal naterial and $1 \pi$ to the food web. Estimates of detrital biom mass in a large shallow estuary are very tentative at best, especially for settled detrital material whose avallabilicy must be measured aqainst depth of burlal into the sediment column, depth of the aeroblc layer of sediment, and depth of the sedithent column experlencing tidal and nontidal advective forces (Trevallion, 1967). As an alternative to actual detrital biomass estimation at each time step, the assumption that enough detrital material in its various forms is present and avallable so that all food-web transfems out of detritus are $11 \mathrm{~m}$ ted by demand may have some merit. With this assumption the term

$$
\sum_{k}\left(\frac{B_{j \rightarrow O^{w}}^{w} j \rightarrow k}{C+\sum_{k} B_{j+k} O_{j \rightarrow k}}\right)
$$

goes to unity for all defritus eaters and 


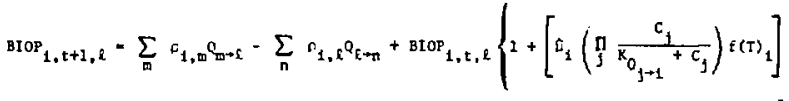

$$
\begin{aligned}
& \longleftrightarrow \text { ald bicassi } \longrightarrow \text { advection } \longrightarrow
\end{aligned}
$$

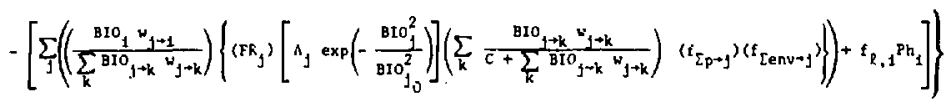

$$
\begin{aligned}
& \varepsilon_{1} \theta_{1}^{T-T_{0}}-E x_{1}-\left(a_{1}+\frac{S_{y}}{z_{\text {phot } 1 c}}\right) A_{1} \exp \left[-1 \frac{\left(T_{\text {opt }, 1}-T\right)^{2}}{\left(T_{\text {opt } 1,1}-T_{D_{1}}\right)^{2}}\right] . \\
& \text { Areppltativat } \longleftrightarrow \text { ש }
\end{aligned}
$$

where

$$
\begin{aligned}
& f(T)_{1}=A_{T_{1}} \exp \left[-\frac{\left(T_{o p t, 1}-T\right)^{2}}{\left(\tau_{o p t, 1}-\tau_{1,0_{1}}\right)^{2}}\right] \text { for } r \leq T_{o p t} \text {, } \\
& f(T)_{1}=A_{T_{1}} \exp \left[-\frac{\left(T_{\text {opt }, 1}-T\right)^{2}}{\left(T_{o p t, 1}-T_{1,0}\right)^{2}}\right] \text { for } T>T_{o p t} \text {, }
\end{aligned}
$$

and the excretion term is

$$
E x_{1}= \begin{cases}a_{1} P_{n e t, 1} & \text { for } P_{\text {net, } 1}>0, \\ 0 & \text { for } P_{\text {net }, 1} \leq 0,\end{cases}
$$

wich $P_{\text {net, }}$ beling the toral photosynthetic production minus respiration.

F1g. 20. The complete primary production equation. 
total consumption is limited primarily by taxon biomass. In confunction with this assumption, it can be assumed that the pollutant concentration of detritus removed from the water column is equal to that of the water column and that detritus removed from the sediment colum has a concentration equal to that of the sediment. Detrital decomposers and the inorganic nitrlents they produce can also be externalized by assigning a flxed rate of nutrient production as a model Import. Nutrients are rarely a principal limiting factor $1 n$ an estuarine system, and thus any error generated in total nutrient avallability will be of little Importance.

Should additional studies indicate that this treatment of detritus is Inadequate, detritus mass-balance equations can be genorated. Figure 21 11lustrates the estuarine detrital cycle in which four detrital components are specified (Shugart er al., 1974). These are suspended dissolved organic matter (DOM), suspended particulate organic matter (POM), setiled DOM, and settled POM. Each of these components could je tracked and balanced separately. However, this would require reconstruction of the excretion term of the biomass equation, incluston of a decomposer mass-balance equation, and far more detalled information on sediment-water colum interactions than is available at this time.

For mass-balance purposes it w111 therefore be extremely advantageous to combine all detrical forms into a single blomass heading and construct a single mass-balance equation. As indicated in Fig. 21, the equat:on is

$$
\begin{aligned}
& \text { detritus }_{t+1, \ell}=\operatorname{DEr}_{t, \ell}+\sum_{i} E_{1}+\sum_{1} M_{1} \\
& +\sum_{i} s_{1}+\sum_{m} I_{N W C, m \rightarrow l} \\
& +\sum_{m} I_{L S C, \pi \rightarrow l}-\sum_{n} o_{M W C, \ell+n} \\
& -\sum_{n} o_{L S C, l+n}-D \\
& -\sum_{j} P_{j+D E T}
\end{aligned}
$$

where

$$
\begin{aligned}
& E=\text { excretion, } \\
& M=\text { mortality, } \\
& \mathrm{s}=\operatorname{set} 11 \mathrm{ng}, \\
& I_{\text {MHC }}=\text { mass water column } 1 \text { mport, } \\
& I_{\text {LSC }}=1 \text { Ink sediment column Import, } \\
& \mathrm{O}_{\text {MHC }}=\text { mass water column export, } \\
& O_{\text {LSC }}=11 \text { nk sediment column export, } \\
& \mathrm{D}=\text { decomposition, } \\
& \mathrm{P}=\text { predation } \text {. }
\end{aligned}
$$

The first three mass addition terms in this equation (excretion, mortality, and settling) have already been calculated by the biomass equation for each caxon. AdvectIve 1mport and export terms can be calculated similarly to advective migration calculations for blotic taxa, since the forces and processes Involved are Identical with those that result in blotic advection.

The presence of a decomposition cerm in the detritus equation is required even though the decomposer populations and processes have been externalized. A given mass of detritus during each time step 


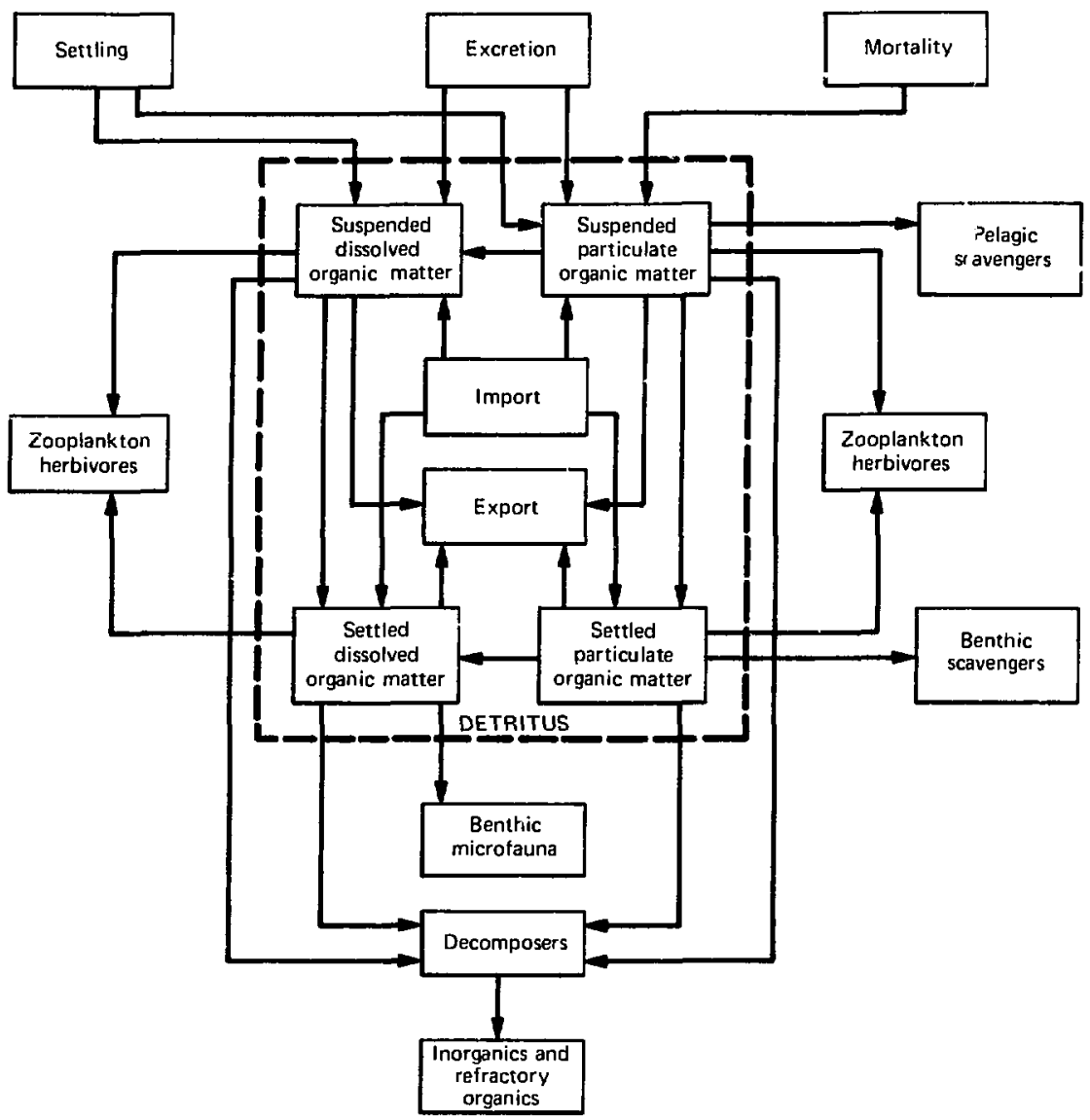

F1g. 21. Estuarine detritus cycle.

will be consufaed by decomposers. Given a constant specific feeding rate for decomposer organisms (averaged over a one-day time step), the size of the decomposer biomass at each time step will be proportioned to and numerically dependent on the available detrital biomass (N1elsen,
1964). Thus the mass of detritus consumed will vary according to available detrital biomass, or

$$
\mathrm{D}_{\mathrm{DET}, t+1}=\mathrm{C}_{\mathrm{DET}}\left(\mathrm{DFT}_{\mathrm{t}, \ell}\right) \text {, }
$$

where $D$ is decomposition. 
This analysis assumes that, since a variety of decomposer spectes exist over the full range of estuarine environmentai conditfons and in the presence of all currently discharged wastes, unde: any given environmental conditions there will be sufficient decomposers to maintain this ratio of decomposers to detritus. Eurthermore, Lt assumes that the adverse effects of any set of pollutants will not affect all decomposer species; hence if some species are retarded by a specific pollutant action, others w111 emerge to mafntain a normative decomposer-detritus relationship and total rate of detritus conversion. Should pollutant concentration sets be encountered that Invalidate this assumption, an appropriate pollutantconcentration dependence can be included directly in Eq. (52), so that

$\mathrm{D}_{\mathrm{DET}, \mathrm{t}+1, \ell}=\mathrm{C}_{\mathrm{DET}}\left(\mathrm{DET}_{\mathrm{t}, \ell}\right) \mathrm{f}_{\sum_{\mathrm{P} \rightarrow \text { de composers }}}$.

Once the detrital blomass has been reduced to a finfte mass, the predation term will return to the normal, previously discussed predation form.

Since most detrital feeders are selective [i.e., consume only settled, or cnly suspended matter (Perkins, 1974) or consume only particulate rather than dissolved organic matter], the $w_{j+D E T}$ term in the detrital feeding equation will require adjustment, Each selectlve feeder will not encounter $\mathrm{DET}_{t, \ell}$ amount of detritus, but rather something less than this mass, depending on the type of detritus preferred. Thus the detritus-feeders preference used in the detritus prediction equation $\$ 11$ be

$$
\left.w_{j \rightarrow D E T}^{*}=\sum_{i}\left(w_{j \rightarrow D E T_{i}}\right)^{\left(\not D E T_{1}\right.}\right)
$$

where \% DET 1 is the fractional percent of total detrital mass that is of detrital type 1 (POM or DOM; suspended or settled); $w_{j-D E T, 1}$ is predator $f^{\prime} s$ preference for detritus type 1.

Finally, pollutant concentrations will be tracked through detritus consumption as previougly Indicated by assuming that the concentration of pollutant in detritus matches the concentration of 1 ts surroundIngs.

This is admictedly an extreme simplification of actual concentrations of pollutants in detritus, which depend on several factors, including the source of the detritus and the length of time 1 t has existed in its present form. However, it is anticipated that errors generated in this manner will, when transmitted through the food web, represent a very small percentage of the total concentration levels.

\section{POLLUTANT CONCENTRATION}

At each time step, the concentration of varfo:s pollutants wll be mapped in the water column, in the sediment column, and within each taxon. The goal here is to predict communfty response to any given level of a specific pollutant or to any given set of pollutant concentrations. While most pollutants tend to concentrate in a specific organ or puscle tissue, it ts extremely disadvantageous to approach their study on this level. So far this study has considered only gross ta:sin biomass. It would be extremely difficult to consider individual organs within each taxon. Fortunately, this does not appear to be necessary. If pollutant effects can 
be related to concentrations within an organ, and if that organ's bionass can be related to an organfsm biomass and this to the total taxon biomass, then the effects can be directly related to the average concentration within the taxon biomass. This Integrative approach can mask local high concentration anomalies; however, this effect will be minituized by this study's concentration on chrontc low-level losding.

With this conceptual basis, the general form of the equation for total taxon pollutant mass is given by the concentration of the previous time step plus the net uptake over one time interval plus the effect of taxon blonass changes, or

$$
\begin{aligned}
& \mathrm{C}_{\mathrm{pT}}{ }_{j+1, t+1, \ell} \\
& =\left\{\text { BIO }_{1, t, l} C_{p_{j+1}, t, l}+\left[\left(C_{p_{j+w a t e r}} u_{i \rightarrow j_{w}}\right)\right.\right. \\
& \left.+\left(c_{p_{j+\text { sed. }}} u_{1+j_{s}}\right)+\left(c_{p_{j \rightarrow f o o d}} u_{1 \rightarrow j_{f}}\right)\right] \\
& \left.-\left(E_{i} C_{p_{j \rightarrow E_{1}}}\right)\right\}-\left[\mathrm{C}_{p_{j+1, t, \ell}} \text { bioloss }_{i}\right. \\
& -a_{1}\left(c_{P_{j+1, t, \ell}} \text { recruitment }_{1+k}\right) \\
& \left.+\sum_{j 1} c_{p_{j+j 1}} \operatorname{bioga1n}_{j 1+1}\right] \text {, }
\end{aligned}
$$

where $u_{1+j}$ ts the uptake rate of pollutant $j$ by taxon $1, c_{p_{j+1, t, l}}$ is the concentration of pollutant $j$ in taxon 1 at time $t$ and node $\ell, C_{j \text { twater }}$ is the concentration of pollutant $j$ in the water colum at node $l$ and time $t$ and $a_{1}$ is the pollutantconcentration factor associated with taxon reproduction activities.
The last three terms of Eq. (55) (enclosed within the brackets) correspond to the mass changes assoctated with the b10mass equation. The biomass-equation terms associated with each mass-change term in $\mathrm{Eq}$. (55) are (1) bioloss, which Includes mortality, predation, as well as outadvection and outmigration; (2) outrecruitment, which includes only the outrecruitment portion of the full recruitment tecm; and (3) biogain, which includes inadvection and inmigration as well as inrecruitment to taxon 1 .

The excretion term here depends only on taxon assimilative characteristics and of the pollutant concentration at the previous time step. Thus this term represents only the amount of each pollutant removed from the organism's internal system. The total pollutant load excreted is equal to this quantity plus the amount not taken up from the food consumed. This latter figure would be 1mportant only for calculation of concentration in detritus.

The $u_{1 \rightarrow j}$ terms in $\mathrm{Eq}$. (5.5) represent taxon uptake rates. Such uptake rates are dependent on the local pollutant availability, taxon characteristics, and prev1ous intemal concentrations, A typical curve for uptake as a function of time is shown in Fig. 22 (Polikarpov, 1966). For

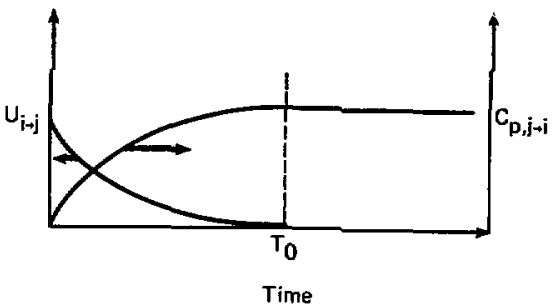

Fig. 22. Typ1cal pollutant uptake rates and concentrations. 
many estuarine species the time $\left(t_{0}\right)$ to reach the maximum pollutant cuncentration is much less than one day, the time-step interval of this study. Thus for many taxa the use of a simple concentration factor (final steady-state concentration) Instead of the functional uptake rate may be appropriate. This interchangeability has not yet been determined.

Once the total taxon pollutant load has been determined by Eq. (55), the pollutant concentration (pollutant per untt taxon mass) can be calculated as

$$
\mathrm{C}_{\mathrm{p}_{j \rightarrow 1, t+1, \ell}}=\left(\mathrm{C}_{\mathrm{pT}} \mathrm{j}_{\mathrm{i}, t+1, \ell}\right)\left(\mathrm{BIO}_{i, t+1, \ell}\right)^{-1}
$$

Curves of pollutant effects, once established, w11l be geared to this concentration term for each taxon. The resulting lethal and sublethal effects will be relnserted into the biomass and primary production equations for the next time-gtep calculation.

\section{Ecological Model Data Requirements}

It is readily apparent that operation of either of the proposed ecological models requires an extensive data base. Mcre specifically, both the $I / O$ and the dynamic model ræquire identification of the followIng:

- All food-web links

- All link $w_{j \rightarrow k}$ values

- Spectfic feeding rates and conversion rates $\left(\mu_{i}\right)$ for all taxa

- Pollutant-uptake rates for all ;otential pollutants by all taxa

- Pollutant effects (by concentration) to include lethal, sublethal, behavioral, and physical

- Human harvest rates

- Environmental tolerances and preferences by taxa.

Moreover, the dynamic model will also require

- Taxa half-saturation constants by pollutant and environmental parameter

- Reproductive and recrultment races, times, controlling factors, etc.
- Advection or migration choice factors.

In addition to this list of specific relationships, the dynamic model contains a number of constants that must be specifled through parametrization techniques for data fitting. This process, of course, requires multiple data points for each parameter.

Obvilously many of these daca are currently nonexistent. Many pollutants are just beginning to be fully explored, and an acceptable seasonal spectesIdentification list has not yet been determined for San Francisco Bay, much less the specific food-web links. Thus fully determinant explicit operation of the models is not yet feasible.

The operational plan of this study is to estimate and extrapolate all required data that cannot be specified and to either approxlmate or disregard suboptimal conditIon modifiers (environmental, pollutant, or population effects) that are not known. In this manner the model will be made Immediately available for operational use, 
and specitic areas for needed research will be identified. It is hoped that this will, in turn, Increase the rate at which new data become available for inclusion into various model parameters.

Such an operational mode will not yield data-point-specific results on an Impact analysis; but even unj, $r$ worst case conditlons it will be able to define the direc- tion that an impact will take, the ecological elements primarily affected, and an order-of-magnitude estimation of that impact. This may be less than an ideal output, but it is no worse than many existing Inputs to the decision-making process in the public sector and should be far better than the intultive evaluations of environmental tmpacts currently used in that process.

\section{Ecological Model Omissions}

As currently designed, both of the ecological models proposed here ontt certain significant elements of the general estuarine ecology. The first of these is macroflora. No provision is currently made to track the growth or size of macroflora. This is not as important in the San Franclsco estuary as it is in many lakes; however, estuarine eel-grass beds are uniquely 1mportant for their role $1 \mathrm{n}$ defining the estuarine fauna. Coastal seaweed beds play a similar role in that environment. Marsh grasses and swamp grasses are less cricical since detritusimport terms cover puch of their primary importance to the estuarine ecology. It will becone desirable to Include eel grasses within the ecological model because of their Important base roles; however, this has not been done to dace.

Waterfowl have also been disregarded in this model effort. This omisston should not have a major consequence in San
Francisco Bay; yet waterfowl fill a top predator slot ior which the ecological model presented here will not compensate. Should this omission prove troublesome, a predation factor for waterfowl w11l be incorporated inio the blomass equation. It is not anticipated that waterfowl will ever be included as a set of separate taxa into this model.

Finally, intertidal specles are handled in a simplefied form by this model. As relatively strict intertidal zonation is present in most West Coast estuaries (RIcketts and Calvin, 2:65) it would be possible to incorporate, taxon by taxon, the effects of varying exposure to air and water. However, the benefits of such an approach have been tentatively deemed Insufficient to justify the added complicacton to benthic, zooplankton, and phytoplankton taxa that would be affected, and the added requirement for input data, equation parametrization, and air-shed modeling. 


\section{Feferences}

Altman, P. L, and D. S. Dittmer, Eds., 1962, B1ology Data Book: Grawth - Including Reproduction and Morphological Development, Federation of American Socteties of FxperImental Biology, Hashington D.C., 1962.

Califounia State Department of Fish and Game, 1972, Ecological Study of the SacramentoSan Joaquin Estuary.

Chen, C. W., and G. T. Orlob, 1975, "Ecologics Simulation for Aquatic Environments," Ecology 55: $475-587$.

Clark, J., and $W$. Browne11, 1973, Flectric Power Plants in the Coastal Zone: Environmental Issues, American Littoral Society, Special Publication No. 7.

De Argel1s, D. L., R. A. Goldsteln, and R. W. O'Ne11, 1975, "A Mode1 for Trophic Interaction," Ecology 56: 881-892.

Enstein, H. A., and R. B. Krone, 1961, "Estuaral Sediment Transport Patterns," Journal of the Hydraulics Division - Proceedings of the American Soclety of Civil Engineers, March, 51-59.

Fillice, F. P., 1958, "Invertebrates from the Estuarine Portion of San Francisco Bay and Some Factors Influencing The1r Istribution," The Wasmann Journal of Blology 16(2): 159-211.

Fox, L. R., 1975, "Factors Influencing Cannfbalism, a Mechanism of Population Limitation in the Predator Notenecta hof fmanni," Ecology 56: 933-941.

Green, J., 1968, The Btology of Estuarine Animals, University of Washington Press, Seattle, Wash.

Harden Jones, F. D., 1968, F1gh Migration, Edward Amold Pub1., Ltd., London.

Hardy, A., 1965, The Open Sea, Houghton Mifflin Company, Boston Mass., Vols. 1 and 2.

Bazel, C. R., et al., 1970, Development of Testing Procedures and Cr1terion for Evaluating 011 Sp111 Clean Up Agents, California State Department of Fish and Game.

Hazel, C. R., et al., 1971, Development of Testing Procedures and Criterton for Evaluating 0i1 Sp111 Clean Up Agents - Terminal Report, California State Department of Fish and Game, Publ. No. 43 .

Isaacs, J. D., 1972, "Unstructured Marine Food Webs and Pollutant Analogues," F1sheries Bu1l. 70 (3): 1053-1059.

Isard, W., 1960, Methods of Regional Analysis, The M.I.T. Press, Cambridge, Mass.

Isard, W., 1972, Ecologic - Economlc Analysis for Regiona1 Development, Free Press, New York.

Kalser Engineers, 1969, San Francisco Bay-Delta Water Quality Control Program (Final Report to the State of California), Tasks II through VI.

Kopperdah1, F., et al., 1971, Evaluation of O1l Sp111 Clean Up Agents (OSCA) and for Furnishing Technical Assistance to the Board In Matters Concerning ofl Spill Clean Up Agents, California State Department of Fish and Game.

Kunin, L., E. Lofting, and J. Sathaye, 1975, Development of State Interindustrial Models for Rocky Mountain Region and California, University of California, Berkeley. 
Lanff, G. H., Ed., 1967, Estuaries, American Association for the Advancement of Science, Washington, D.C., Publ. No. 83.

McLusky, D. S., 1971, Ecology of Estuaries, Heinemann Educational Books, Ltd., London.

Nelson, A. W., and R. J. Lerseth, 1972, A Study of Dispersion Capability of San Franc1sco Bay Delta Waters, Calffornla State Water Resources Control Board.

Nielsen, E. S., 1964, "Recent Advances In Measuring and Understanding Marine Primary Production," Journal of Ecology, 52: 119-130.

O'Neill, R. V., 1969, "Indirect Estimation of Energy Fluxes in Animal Food Webs," Journal of Theoretical Blology 22: 284-290.

Park, Ro A., et al., 1974, "A Generalized Model for Simulating Lake Ecosystems," Simulation, August, 33-49.

Pearson, Storrs, and Sellech, 1965-1966, A Comprehensive Study of San Francisco Bay, Final Report, University of Calffornia, SERC, Vols. 1-7.

Perkins, E。 Jo, 1974, The Biology of Estuaries and Coastal Waters, Academic Press, New York.

Polikarpov, G. G., 1966, Radioecology of Aquatic Organ1sms, Re1nhold, New York.

Ricketts, E。 F., and J. Calvin, 1968, Between Paclfic I1des, 4th ed,, Stanford University Press, Stanford, Calif.

Shugart, H. H., et al., 1974, "IEEM: A Terrestrial Ecosystem Energy Model for Forests," Oecol. Plant 2(3): 231-264.

Stoevener, $H_{0}$, et al., 1972, Mult1-D1sc1plinary Study of Water Qualicy Relationsh1ps: A Case Study of Yaquina Bay, Ore., Oregon State University Sea Grant Program, Special Report No. 348 .

Trevallion, Aa, 1967, "An Investigation of Detritus in Southampton Water," Journal of the Marine Biology Association of the United Kingdom 4?: 523-532.

Water Resources Engineers, 1965, A Water Quality Model of the Sacramento - San Joaquin Delta, U.S. Public Health Service, Region 9.

U.S. Army Eng1neer District, San Francisco, Dredge Disposal Study - San Francisco Bay and Estuary, Append IX F, "Crystalline Matrix Study," and Append1x I, "Pollutant Avaflability," U.S. Army Corps of Engineers, San Franc1sco, Calif. 